
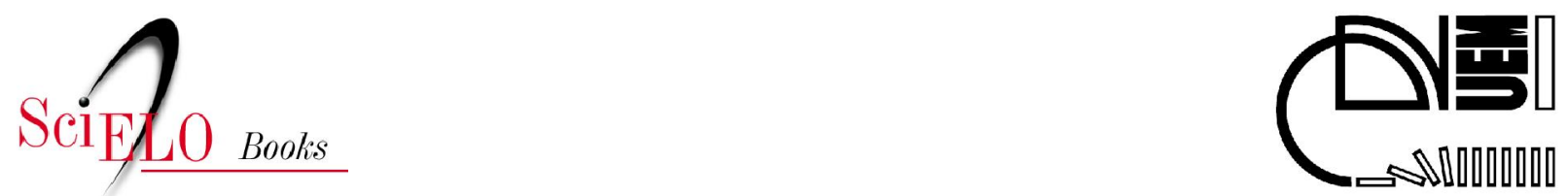

\title{
III. Problemas da conquista de terras e análise dos processos da colonização agrária em sua diferenciação espaço-temporal
}

\author{
Paulo Astor Soethe (org.) \\ Daniel Martineschen (coord.) \\ Caio Heleno da Costa Pereira \\ Dionei Mathias \\ Elisete Antoniuk \\ Fernanda Boarin Boechat \\ Frederico Füllgraf \\ Natasha Pereira da Silva \\ Sibele Paulino \\ Sirlene Nair Neubauer \\ (transl.)
}

\section{SciELO Books / SciELO Livros / SciELO Libros}

SOETHE, PA., org. MARTINESCHEN, D., et al., transl. KOHLHEPP, G. Problemas da conquista de terras e análise dos processos da colonização agrária em sua diferenciação espaço-temporal. In: Colonização agrária no Norte do Paraná: processos geoeconômicos e sociogeográficos de desenvolvimento de uma zona subtropical do Brasil sob a influência da plantação de café [online]. Maringá: Eduem, 2014, pp. 45-80. ISBN 978-85-7628-655-4. Available from SciELO Books <http://books.scielo.org $>$.

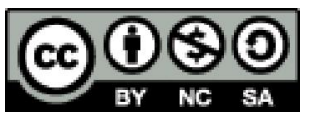

All the contents of this chapter, except where otherwise noted, is licensed under a Creative Commons Attribution-Non Commercial-ShareAlike 3.0 Unported.

Todo o conteúdo deste capítulo, exceto quando houver ressalva, é publicado sob a licença Creative Commons Atribuição Uso Não Comercial - Partilha nos Mesmos Termos 3.0 Não adaptada.

Todo el contenido de este capítulo, excepto donde se indique lo contrario, está bajo licencia de la licencia Creative Commons Reconocimento-NoComercial-CompartirIgual 3.0 Unported. 


\section{PROBLEMAS DA CONQUISTA DE TERRAS E ANÁLISE DOS PROCESSOS DA COLONIZAÇÃO AGRÁRIA EM SUA DIFERENCIAÇÃO ESPAÇO-TEMPORAL ${ }^{38}$}

\section{OS PRIMÓRDIOS DA COLONIZAÇÃO NA PROVÍNCIA GUAYRÁ NOS SÉCULOS XVI E XVII}

Foi apenas em meados do século XVI que a região montanhosa coberta de florestas localizada a leste do rio Paraná e ao sul do rio Paranapanema e pertencente ao império colonial espanhol despertou de fato o interesse de seus senhores. Um sistema de trilhas indígenas existente desde tempos précolombianos permitiu que os espanhóis saíssem da costa leste do continente e chegassem a Asunción por via terrestre. A famosa expedição de Alvar Núñez Cabeza de Vaca partiu em 1541/42 da foz do rio Itapocu, na fronteira entre as zonas portuguesa e espanhola - atualmente no estado brasileiro de Santa Catarina -, para o noroeste e encontrou, na região dos Campos do planalto do Paraná, o antigo caminho transcontinental chamado pelos índios de 'Peabiru' (Mapa 8). Essa trilha, que passava pelas florestas de araucárias e florestas subtropicais e conduzia em direção oeste às Sete Quedas do rio Paraná, foi utilizada pelos espanhóis somente até o rio Piquiri. a partir dali, eles mudaram seu curso para o sul, em direção a Asunción ${ }^{39}$.

\section{a) Assentamentos espanhóis}

Quando o impulso de expansão espanhol, que partia da cidade de Asunción, fundada em 1537, foi direcionado para leste devido à ameaça indígena na região da foz do Rio da Prata, surgiu em 1554 o primeiro assentamento na margem oeste do rio Paraná, poucos quilômetros acima de suas quedas: Ontiveros $^{40}$. Com isso, os espanhóis puderam começar a utilizar e proteger o caminho de Peabiru em sentido leste. Contudo, Ontiveros foi novamente abandonada três anos mais tarde, depois que a Ciudad Real del Guayrá foi fundada em 1556 na margem oposta, na confluência dos rios Piquiri e Paraná, e elevada a capital da província.

O avanço espanhol para o leste chegou ao seu posto avançado mais extremo em 1576, com a fundação de Villa Rica del Espírito Santo em uma região isolada no meio da floresta tropical às margens do rio Ivaí. A atividade espanhola de assentamento encontrou aqui a resistência fervorosa dos índios Guarani, que seriam forçados pelos donos de terras a trabalhar sob o sistema das encomiendas.

A influência espanhola no atual estado do Paraná - pertencente à Espanha segundo o Tratado de Tordesilhas - limitou-se, devido à densidade das florestas, às regiões ao longo dos rios principais e em pontos especialmente importantes do ponto de vista estratégico. Em Ciudad Real havia, por volta de 1565, entre 200 e 300 espanhóis, e a população total da cidade compreendia, contando com as esposas indígenas e os filhos desses espanhóis, cerca de 4000 habitantes (WILHELMY; ROHMEDER 1963, p. 407). A região de fronteira entre as áreas de influência espanhola e portuguesa permaneceu predominantemente de posse dos indígenas. Em relatos da época, a quantidade de índios Guarani na

Tradução de Daniel Martineschen e Sirlene Nair Neubauer.

39 O lansquenê alemão Ulrich Schmidel também chegou ao caminho de Peabiru em sua travessia de Oeste a Leste do continente americano partindo de Asunción em 1552/53; esse caminho deveria levá-lo pela costa até São Vicente, partindo do Sul e passando pelos rios Monday e Iguaçu (sobre isso, cf. MAACK, 1959, p. 35ss.).

40 A data de fundação de Ontiveros é controversa. Com base em várias fontes, Wilhelmy e Rohmeder (1963, p. 406) indicam o ano de 1543 (no rio Piquiri), Samhaber (1939, p. 228) o ano de 1549 e Maack (1959, p. 37) o ano de 1554. Contudo, Ontiveros e, por conseguinte, o acesso direto ao Alto Paraná e ao caminho de Peabiru não poderiam ter sido conhecidos antes da viagem de Schmidel, uma vez que este alcançou o Peabiru no início de 1553 somente na bacia do Piquiri, depois de muitos desvios a partir do sul. Segundo Maack, relatos do fundador Irala à coroa espanhola e ao Consejo de las Indias indicam que, depois de ter encontrado as quedas do rio Paraná algumas semanas após Schmidel partir de Asunción em 1553, Irala estabeleceu ali em 1554 uma base fortificada. 
região de Guayrá, que ficava a leste do rio Paraná e limitada pelo rio Paranapanema ao norte e pelo Iguaçu ao sul, era estimada em cerca de 200 mil (SAMHABER, 1939, p. 240).

A fronteira, isto é, a zona neutra sem assentamentos entre os impérios coloniais da Espanha e de Portugal na região que atualmente corresponde ao Paraná, manteve-se assim também durante o período da união pessoal sob Filipe II, após 1580. Os problemas administrativos da gigantesca região de La Plata fizeram com que somente em 1617, após intervenção do governador Hernandarias de Saavedra, viesse a ser separada administrativamente a região de Guayrá: Villa Rica e Ciudad Real, bem como Santiago de Xerez no alto rio Paraguai e a capital Asunción, tornaram-se parte da província do Paraguai ou Guayrá. As comunidades-filhas fundadas no último quarto do século XVI seguindo o curso do rio a partir de Asunción - Santa Fé, Buenos Aires (fundação secundária), Corrientes e Concepción del Bermejo foram integradas à província de La Plata. Contudo, o isolamento dos postos avançados espanhóis em cidades na região de Guayrá manteve-se mesmo depois do reordenamento político-administrativo (MÖRNER, 1953, p. 53-54) . $^{4}$

\section{b) Reduções jesuíticas guaranis}

Quando a economia de encomiendas começou a se desenvolver de maneira aparentemente indesejada também no Paraguai, o governador Hernandarias chamou para o país, em 1588, missionários jesuítas vindos do Brasil, onde já estavam ativos desde a metade do século XVI"2. Um decreto real de 1601 ordenara a pacificação dos índios sem repressão violenta nem escravização ${ }^{43}$. Recaiu sobre os jesuítas - tanto segundo as ordenanzas de poblaciones do governo espanhol de $1573^{44}$, quanto segundo a determinação do Superior Geral da Companhia de Jesus, Aquaviva - a difícil tarefa de assentar os índios Guarani de Guayrá em colônias fixas separadas, protegê-los da exploração por parte de encomenderos espanhóis, cristianizá-los e também educá-los tanto para a agricultura quanto para o artesanato.

No âmbito dessa atividade, acreditava-se obter uma valorização das regiões no extremo leste do império colonial espanhol e poder avançar para o sudeste até a costa atlântica de Santa Catarina.

Em 1604 foi fundado o estado missionário jesuíta do Paraguai. OSuperior Provincial Diego de Torres, que já tivera experiências com essas atividades no Peru, foi encarregado de organizar a construção de colônias missionárias, as chamadas reduções.

Com a construção das reduções Guarani em Guayrá iniciou-se uma profícua atividade por parte dos missionários jesuítas na bacia do Paraná-Paraguai que durou mais de $150 \operatorname{anos}^{45}$ e, com isso, uma nova fase da colonização na região oriental de fronteira na bacia do Rio da Prata.

Os rios Paranapanema e Ivaí, afluentes do Paraná, bem como seus subafluentes Tibagi e Corumbataí (Mapa 8), serviram de ponto de partida para as atividades jesuíticas e de localização para as reduções. Não obstante as condições geográficas favoráveis ao transporte proporcionadas por rios navegáveis, as reduções eram ameaçadas por enchentes e pelo perigo da malária nos vales dos rios. Em 1610 ocorreu a fundação de Loreto, na confluência do rio Pirapó no rio Paranapanema, e pouco a Leste dali foi fundada San Ignacio. Até 1628, sobretudo a partir do início da década de 1620 e sob o comando do Superior Montoya, surgiram mais 11 reduções, na maioria comunidades-filhas: San José, San Francisco Xavier, Encarnación e, mais para sudeste na região de fronteira das florestas de Campos, San Miguel, todas às margens do rio Tibagi. No curso médio do rio Ivaí foram fundadas San Pablo e San Antonio, e no curso superior, Jesus María e nas proximidades San Pedro; surgiram às margens do Corumbataí as reduções de San Tomás, Arcángeles e Concepción ${ }^{46}$. Algumas aldeias indígenas foram convertidas em reduções, enquanto algumas colônias missionárias foram reinstaladas. Os índios das 13 reduções, cuja população

41 Os esforços de Hernandarias em estabelecer relações comerciais entre Ciudad Real e Villa Rica, por um lado, e São Paulo, por outro, não foram sancionados pela coroa.

42 A atividade missionária jesuítica no Peru começara em 1568.

43 Cédula Real de 21/11/1601, cf. Hernandez (1913, II, p. 97).

44 Sobre isso cf. Garsch (1934, p. 54 e 60): "Sob a influência dos missionários deveria ser criado um espaço vital para os nativos que compreendesse áreas habitacionais, comerciais e de transporte e que estivesse em constante transformação para se adaptar a novas e mais elevadas exigências culturais."

45 Sobre isso, cf., entre outros, Fassbinder (1926), Garsch (1934), Mörner (1953), Aigner (1959) e Otruba (1962).

46 Os dados sobre os nomes, a localização exata e, em certos casos, até sobre a existência dessas e de outras reduções são muito variados. Sobre essa questão foram consultados sobretudo Hernandez (1913, I, p. 50ss.); Dorfmund (1963, mapa à p. 95); ElKhatib (Org.). História do Paraná, 1969, I, p. 50ss.; Chmyz (1963, p. 104) e o Mapa do Estado do Paraná, 1969. 
beirava os 40.000 (SAMHABER, 1939, p. 240), eram na sua maioria guaranis, mas havia também carijós e tupis das regiões vizinhas nas fronteiras oeste e leste, respectivamente.

A atividade bem-sucedida missionária e de colonização realizada pelos jesuítas se baseava no reconhecimento da posição privilegiada dos caciques na ordem social indígena, no acordo fechado com estes na fundação das reduções e no pagamento dos trabalhos realizados pelos indígenas. Além disso, a falta de uma tradição cultural e religiosa bem como de consciência política facilitou o trabalho com os Guaranis - ao contrário do que ocorreu com os povos andinos (MÖRNER, 1953, p. 66 e 201).

O florescimento rápido das reduções e a grande quantidade de indígenas que foram assentados ali privaram a aristocracia espanhola do acesso a eles, o que fez com que logo surgisse uma forte oposição aos jesuítas por parte dessa aristocracia. O impacto das ordenanzas do visitador Alfaro e a proibição geral da escravização violenta de índios abalaram o sistema econômico e, consequentemente, a existência dos assentamentos espanhóis ${ }^{47}$. A emigração e a fuga da força de trabalho guarani para as reduções encontrou violenta resistência por parte da população espanhola em Ciudad Real, e especialmente em Villa Rica.

A construção das reduções seguia um planejamento preciso. A planta ortogonal, com ruas perpendiculares, fora determinada pelo vice-rei espanhol Francisco de Toledo para pueblos indígenas. Em torno da praça quadrangular no centro da colônia havia, de um lado, a igreja, a casa dos missionários com salas de aula, oficinas e depósito, a casa das viúvas e o cemitério. Os outros lados da praça eram ocupados pelas casas dos indígenas ordenadas em grupos de quatro a seis, todas cobertas com palha e com paredes de pau-a-pique, conforme a tradição de construção guarani.

O fato de os índios Guarani já conhecerem uma agricultura primitiva antes da chegada dos espanhóis contribuiu substancialmente para o sucesso econômico das reduções. A empatia dos missionários jesuítas, em sua maioria espanhóis, fez o resto durante o lento processo de habituação de seus protegidos aos trabalhos coordenados. Os trabalhos de agricultura no sistema de roça em terra comum eram decididos diariamente e conduzidos sob uma rígida divisão de trabalho. A organização cooperativa das reduções deixava livre uma área de cultivo particular (amambaê) semelhante a um pequeno quintal para cada uma das várias famílias, que tinham de trabalhar somente dois dias por semana na terra comum (tupambaé). No sistema de rotação de terras praticada com pau-cavador, um período de cultivo de dois a três anos era seguido por um período de pousio de 6 a 12 anos.

A gestão de plantações maiores e de hortas coexistiam segundo a diferenciação de direito de posse já mencionada. Além do cultivo de milho, mandioca, batata-doce, painço, cevada, algodão e cana-deaçúcar, bem como da manutenção de pomares, praticava-se a pecuária, que compreendia tanto gado bovino quanto ovino. ${ }^{48}$ Contudo, os jesuítas atingiram o melhor resultado com as plantações de Yerba Mate (erva-mate, Ilex paraguaiensis). Apesar de o mate ser nativo da floresta mista das áreas altas do Paraná, os jesuítas procuraram organizar a colheita de modo mais racional em plantações próprias, e eliminar tanto os problemas de transporte quanto o risco de captura dos índios por encomenderos ou bandeirantes, ocorrência comum na economia de colheita do mate em regiões afastadas.

Depois do chá-mate se tornar, na primeira metade do século XVII, um produto de mercado do império colonial espanhol, estabeleceu-se uma situação de concorrência na exportação de mate entre as reduções jesuíticas e os donos de terra - que sofriam com a falta de mão de obra -, principalmente de Villa Rica. Posteriormente, surgiram as suntuosas igrejas das missões, financiadas principalmente com as receitas da venda do mate. Além disso, realizou-se com sucesso a formação profissional dos índios

A redução de Arcángeles também é mencionada como Los Angeles e Siete Arcanjos de Taioba. - A localização de Jesus María no Mapa do Estado do Paraná de 1969 (curso inferior do rio Ivaí, hoje município de Amaporã) difere muito das outras fontes. Duvida-se de que as reduções de Copacabana (no curso inferior do rio Piquiri?) e de Santa Maria (perto de Foz do Iguaçu?) tenham chegado a ser fundadas.

47 As ordenanzas emitidas em 1611 por Francisco de Alfaro em Asunción se baseavam em relatos de jesuítas. O servicio personal dos indígenas estava proibido; espanhóis, mestiços e negros não podiam entrar nas reduções, e os indígenas das reduções não podiam ser mantidos no sistema de encomiendas e estavam livres de pagar tributos por 10 anos. No entanto, depois de passado esse período, os indígenas de Loreto e de San Ignacio, isto é, homens entre 18 e 50 anos de idade, tinham de prestar servicio personal aos encomenderos dois meses por ano (MÖRNER, 1953, p. 67Sss. e 73; GARSCH, 1934, p. 86; EL-KHATIB (Org.). 1969, I, p. 52, cf. também p. 9).

48 Cf. a esse respeito Hernandez (1913); Garsch (1934) e Aigner (1959). Apesar da proibição da coroa portuguesa, chegaram a Asunción em 1555 as primeiras cabeças de gado na famosa expedição das 'sete vacas e um touro', que se tornou o ponto de partida do processo inovativo da criação de gado na região cisplatina (cf. PFEIFER, 1967, p. 172). 
para a tecelagem, a marcenaria e a ferraria, bem como para a produção de artigos têxteis de lã e algodão, na atual região do Paraná no início do século XVII, provavelmente em um estágio inicial primitivo. ${ }^{49}$

Não há relatos sobre a extensão do arroteamento e sobre a utilização da rotação de culturas para a região do Guayrá. Além do mais, viviam em Loreto - a redução mais importante dessa província - cerca de 2.000 famílias em 1628, num total de 12 mil pessoas que tinham de ser providas dentro do sistema econômico autossuficiente da colônia. ${ }^{50}$

Além das disputas internas na província da missão, que se acenderam entre os colonos e os missionários espanhóis por conta do trabalho escravo e do tributo obrigatório dos índios Guarani, chegou ao Guayrá uma ameaça externa muito mais forte.

A localização geográfica das colônias missionárias do Guayrá na região de fronteira luso-espanhola gerou, já em 1611, um choque com os caçadores de escravos que avançavam a partir de São Paulo em direção oeste e sudoeste..$^{51}$

A grave falta de mão de obra nas plantações de cana-de-açúcar no litoral brasileiro diminuíra perceptivelmente desde que se começou a introduzir escravos negros africanos em 1574, porém quando a Holanda obteve na década de 1620 o controle absoluto sobre o tráfego marinho na costa leste sulamericana, não havia mais como se garantir um suprimento regular de escravos. Por esse motivo, os paulistanos organizavam as chamadas 'malocas', caçadas aos índios Tupi e Guarani dispersos, para cobrir sua demanda por força de trabalho. ${ }^{52}$ Depois das reviravoltas geográficas decorrentes da colonização na província missionária do Guayrá, que levaram os índios antes dispersos a se estabelecerem nas recém-fundadas colônias missionárias fechadas, criou-se aqui um alvo lucrativo para os 'mamelucos'. ${ }^{53}$ Em vez das difíceis caçadas a índios na densa floresta tropical, a partir de então podia-se capturar em grande quantidade os índios concentrados nas reduções, convertidos ao cristianismo e já acostumados ao trabalho no campo. Os participantes das bem planejadas e equipadas 'bandeiras', os 'bandeirantes', viajavam pelos rios Tietê e Paraná em direção sudoeste, ou avançavam para o centro da província missionária passando pelo antigo caminho indígena, apesar da paz entre Espanha e Portugal. Suas ações, partindo com frequência de Piratininga, eram chanceladas extraoficialmente pelas autoridades em São Paulo. A esperança dos jesuítas de que muitas forças fossem deslocadas de São Paulo por causa da ameaça de invasão holandesa em Pernambuco falhou.

Em 1628 apareceram, às margens do Tibagi, quatro 'bandeiras'54 sob o comando do famoso Antônio Raposo Tavares e do proprietário de plantações de cana-de-açúcar Manuel Prêto. As reduções Encarnación e San Miguel, bem como Jesus Maria e San Antonio no alto Ivaí foram destruídas de janeiro a março de 1629, e milhares de índios foram capturados se não tinham conseguido escapar antes como ocorreu em San Miguel, Arcángeles, San Tomás e San Pablo. ${ }^{55}$

Os índios que escaparam do ataque foram reunidos novamente pelos jesuítas e distribuídos nas reduções restantes. Contudo, em 1630 somente as duas colônias missionárias mais antigas e isoladas às margens do rio Paranapanema ainda tinham permanecido intocadas.

Em face da ameaça permanente dos paulistanos, ocorreu no final de 1631 a evacuação de Loreto e San Ignácio, bem como o deslocamento das reduções em direção à região do alto Paraná, em ambas as

49 Tanto o artesanato e o comércio quanto a agricultura das reduções tiveram seu real desenvolvimento somente depois de 1680 , sobretudo após o ano de 1700 sob a influência de jesuítas vindo de várias províncias alemãs da ordem, que, ao contrário dos missionários espanhóis, também tinham formação para o artesanato, a agricultura, a medicina, tinham educação escolar e musical (QUELLE, 1934/35, p. 280-81). Não há dados estatísticos da época sobre a região do Guayrá.

50 Em comparação com os 40 mil índios cristianizados que viviam nas reduções de Guayrá, a quantidade de habitantes espanhóis de Ciudad Real, Villa Rica e Xerez era infimamente pequena, totalizando pouco mais de 1000 pessoas (SAMHABER, 1939, p. 240-41).

51 Em 1612 o governador de Buenos Aires recebeu uma queixa do cabildo de Ciudad Real contra portugueses de São Paulo que teriam perambulado pela região para capturar índios, tendo capturado mais de 3.600 deles (TAUNAY, 1919 , p. 451 e HOLLANDA, 1949 no seu todo).

52 Cf. a esse respeito, entre outros, Franco (1940) e Taunay (1946).

53 Descrição dos jesuítas para a população mestiça de São Paulo originária da mistura de imigrantes portugueses e mulheres indígenas. A origem do nome vem ou do termo Tupi mamã-ruca para 'mestiço', ou do árabe mamaluk, possivelmente uma alusão aos temidos mamelucos no Egito.

54 Essas ‘bandeiras' saíram da cidade de São Paulo com 69 paulistanos, 900 ‘mamelucos' e cerca de 3000 índios Tupi como tropas auxiliares em setembro de 1628 (EL-KHATIB, 1969, 1, p. 54).

55 Em San Antonio: 2000 capturados; Jesus Maria: 1500 (SAMHABER, 1939, 2, p. 241-242). 
margens do rio. Mais de 12 mil índios viajaram com os jesuítas sob o comando de Montoya em mais de 700 jangadas até Ciudad Real. Aqui as Sete Quedas do Paraná tiveram de ser contornadas, deixando-se as jangadas e canoas pelo caminho, e o resto do caminho teve de ser feito a pé. Isso se deu com muitas dificuldades e perdas, sob ameaça constante dos guaireños espanhóis em Ciudad Real que esperavam obter mais mão de obra com os índios fugidos. Somente cerca de um terço dos moradores indígenas das reduções conseguiu chegar às novas áreas das missões.

Entre 1629 e 1632 os 'bandeirantes' tinham escravizado dezenas de milhares de Guaranis retirados de reduções e os levado para Santos e para o Rio de Janeiro, onde o mercado escravista prosperava apesar de uma grande parte dos capturados terem morrido na viagem (MÖRNER, 1953, p. 91). ${ }^{56}$

Depois do deslocamento das reduções Guarani, os paulistanos direcionaram seus ataques a partir de então diretamente às cidades espanholas, cujos moradores não tinham percebido a posição estratégica das colônias missionárias como muralha de proteção contra os ataques portugueses em direção oeste. Em 1632 Ciudad Real e Villa Rica tiveram de ser abandonadas. ${ }^{57}$

O impulso colonizatório pontual dos jesuítas na região que atualmente corresponde ao Paraná deve ser analisado sob o aspecto da atividade missionária que durou pouco menos de duas décadas. As invasões dos 'bandeirantes' destruíram os sucessos colonizatórios e econômicos das reduções da província Guayrá já na sua fase de construção. Desenvolvimento e florescimento completos só foram vivenciados pelas reduções missionárias indígenas na primeira metade do século XVIII, depois do deslocamento para a região missionária de Tape (atualmente no noroeste do Rio Grande do Sul) e para a região interfluvial dos rios Uruguai e Paraná (atualmente a argentina Misiones), onde surgiu o novo centro da atividade missionária (EIDT, 1971, p. 36ss.), bem como para o vizinho Paraguai.

A situação político-geográfica dos estados missionários sul-americanos localizados nas planícies da região de fronteira luso-espanhola ${ }^{58}$ era a mesma das missões espanholas no México e na Califórnia. Na sua função destaca-se, contudo, um contraste marcante: no México e na Califórnia o mecenato real permitia que os missionários tivessem uma dupla função ao servir o Estado e a Igreja. Por parte do Estado, as reduções de fronteira recebiam uma pequena guarnição para segurança militar contra ataques de tribos indígenas inimigas e para o controle dos índios das reduções.

Por outro lado, as reduções Guarani dos jesuítas no Guayrá tiveram de estabelecer uma força armada própria que tinha de estar sempre à disposição das autoridades espanholas, que por sua vez nada faziam por iniciativa própria para proteger as reduções no Guayrá contra os 'bandeirantes' paulistanos. ${ }^{59} \mathrm{O}$ fato de o governador do Paraguai, Céspedes, possuir uma plantação de cana-de-açúcar no Brasil sendo genro do governador no Brasil, Martim de Sá, alimentava a suspeita de cumplicidade, ou, mais precisamente, de tolerância com relação à captura de escravos por interesses egoístas. ${ }^{60}$

Mesmo depois da mudança para a região missionária de Tape (atualmente no noroeste do Rio Grande do Sul), os paulistanos continuavam a ameaçar as reduções que foram deslocadas para norte e noroeste, mas que a partir de então já conseguiam se organizar militarmente e munir parcialmente os índios com armas de fogo. Em 1639 e 1641, os ‘mamelucos’ opressores foram combatidos em Caazapaguazú,

56 A caminhada da redução Jesus Maria até São Paulo durou 47 dias. Segundo Schmieder (1962, p. 417), o total de índios capturados das missões compreendia, entre 1628 e 1630, de mais de 60 mil.

57 Villa Rica foi finalmente estabelecida no interior do Paraguai depois de seis transferências de local (WILHELMY; ROHMEDER, 1963, p. 407).

58 Além do estado missionário do Paraguai, havia ainda os seguintes estados missionários jesuíticos na América do Sul: Maynas (1638) no rio Marañón no Leste do Equador; Mojos (1684) na bacia do Mamoré no nordeste da atual Bolívia; e Chiquitos no alto Paraguai, fundada em 1691. Entre as outras ordens que fundaram estados missionários, deve-se mencionar sobretudo os capuchinhos catalães e a sua região missionária no baixo Orinoco existente desde a metade do século XVII (QUELLE, 1934/35, p. 274ss.).

59 Essas diferenças nas missões da América hispânica foram especialmente enfatizadas por Bolton (1917 apud MÖRNER, 1963, p. 200) - cf. a esse respeito as considerações feitas em Pfeifer (1970) sobre a política de missões e de frontera na Frontera del Norte da Califórnia durante a primeira metade do século XIX.

60 Céspedes foi testemunha, em uma parada intermediária em São Paulo durante sua viagem da Espanha ao Paraguai, da mobilização de algumas bandeiras; protocolou um protesto oficial e alertou os jesuítas no Guayrá, com quem ele, apesar disso, acabou entrando em conflito pouco tempo depois. Com base nas alegações dos jesuítas, ele foi deposto em 1631 por omissão de auxílio para as reduções no Guayrá contra os paulistanos (MÖRNER, 1953, p. 89 e 91). Segundo a opinião de Quelle (1934/35, p. 279), os espanhóis consideravam os estados missionários como sendo estruturas autossuficientes, uma vez que lhes era proibido entrar nelas. Por esse motivo, a proteção das regiões das missões também era incumbência dos jesuítas que lá exerciam domínio e administração. 
ou, mais especificamente, em Mbororé, enquanto as colônias missionárias permaneceram intocadas por décadas. ${ }^{61}$

Depois que isso solucionou o problema dos deslocamentos constantes das reduções - causados pelas ameaças dos paulistanos - , a construção das colônias pôde ser realizada pela primeira vez de maneira sistemática, especialmente sob a influência de jesuítas alemães e holandeses. ${ }^{62}$

Inteligência, formação ampla, disciplina rígida, senso de missão, grande coragem e vontade de ferro, grande capacidade de comunicação, habilidade e um bom senso de organização eram traços distintivos dos missionários jesuítas, cujos sucessos e, principalmente, métodos de condução das reduções não estão livres de controvérsia. ${ }^{63}$

Com a extinção das reduções indígenas jesuítas e das colônias urbanas espanholas, a área do atual estado do Paraná passou da soberania espanhola para a área de influência portuguesa sob a pressão dos 'bandeirantes' paulistanos. ${ }^{64}$ Contudo, isso significou (por causa da disposição espacial da economia e da colonização brasileira) uma posição periférica em um local isolado sem o atrativo de recursos minerais. As regiões despovoadas do norte e do centro do Paraná, em cujas florestas ainda se mantinham alguns poucos grupos indígenas esparsos, caíram em total esquecimento. As ruínas soterradas de Villa Rica só foram redescobertas perto do final do século XVIII por uma patrulha militar brasileira (MAACK, 1937, p. 212).

Contudo, a colonização extensiva do Norte do Paraná começou somente cerca de três séculos após o fim do estado jesuíta no Guayrá, quando a pressão da população de São Paulo e a expansão cafeeira determinada pelo progresso econômico iniciaram a exploração moderna dessa região.

\section{BASES DA DIVISÃO ECONÔMICA E SOCIOESPACIAL DO PARANÁ NOS SÉCULOS XVIII E XIX}

Com o restabelecimento do abastecimento de escravos africanos para as plantações de cana-deaçúcar próximas da costa, e com o começo da fase de desenvolvimento da mineração em Minas Gerais, modificou-se a motivação das relações estabelecidas pelos paulistanos com as partes que faziam fronteira ao sul da área colonial portuguesa.

Se no século XVII ainda dominavam objetivos puramente estratégicos com a fundação de fortificações militares na costa sul do Brasil,$^{65}$ o interesse de São Paulo direcinava agora para a exploração econômica do gado semisselvagem dos 'Campos limpos' ao sul.

Os jesuítas que retornavam para o Rio Grande do Sul pelo Rio Uruguai a partir de 1682 haviam fundado as Sete Missões na região fronteiriça da floresta e dos 'Campos' ${ }^{66} \mathrm{Na}$ área de floresta próxima à colônia no planalto de trapp escarpado a oeste, praticou-se a coivara e explorou-se as Yerbales, plantações de Ilex espalhadas pelas áreas altas. Nas regiões de estepe ao sul do Ibicuí e do Jacuí se localizavam as pastagens naturais da Campanha - que já tinham sido utilizadas durante o período de colonização dos jesuítas a oeste do Uruguai como área de recuo dos rebanhos bovinos nos casos de ataques de

61 Cf. a esse respeito Hernández (1913, I, p. 16ss.). O retorno para a região do Rio Grande do Sul e a fundação dos famosos 'Sete Povos da Banda Oriental do Uruguai' ocorreu, contudo, somente a partir de 1687 (HANSEL, 1958, p. 8ss.). Os jesuítas foram definitivamente expulsos do império colonial espanhol em 1767/68.

62 No âmbito da construção civil, desenvolveu-se a 'casa de adobe' coberta com telhas e com uma varanda na parte frontal. As suntuosas igrejas surgiram perto do final do século XVII. Na agricultura firmou-se uma lavoura primitiva com arado, e além disso instalaram-se grandes fazendas de criação de gado nos 'Campos' das Sete Missões. Inovações como o arado, utilização do ancinho (SCHMIEDER, 1962, p. 396), pecuária e o cultivo de hortaliças se estabeleceram sobretudo graças aos missionários jesuítas alemães (FASSBINDER, 1926, p. 89).

63 Cf. a esse respeito, entre outros: Métraux (1949, p. 645) e Mörner (1953, p. 206).

64 Foi só com o Tratado de Madrid em 1750, e definitivamente com a troca de regiões (Colônia Sacramento - Missões Orientais) no Tratado de Ildefonso, em 1777, que o avanço português em direção Oeste foi legalizado, e as fronteiras brasileiras atuais se estabeleceram nessa região.

65 Além disso, a ocorrência de ouro aluvial entre 1630 e 1640 atraiu moradores de Iguape para a região da atual Paranaguá e para Assungui, e os levou a fundar colônias primitivas (BERNARDES, 1952, p. 431/33).

66 Cf. a esse respeito também Porto (1943). 
espanhóis vindos de Santa Fé. As cabeças de gado da chamada 'Vacaria do Mar' tinham se multiplicado amplamente até a metade do século XVIII. ${ }^{67}$

Os jesuítas conheciam dois sistemas de pecuária, cuja disposição espacial dá uma visão importante sobre o processo de desenvolvimento da configuração cultural do sul: 'vacaria' e 'estancia'.

A pecuária das 'vacarias', a forma extensiva da economia meio selvagem de pecuária nos limites do ecúmeno, corresponde à forma econômica do anel mais externo dos Anéis de Thünen. Os produtos dessa zona eram couro e carne-seca ('charque'), e em menor escala sebo e gordura.

Ao contrário da abordagem econômica puramente extrativista do gado das 'vacarias', as 'estancias' ficavam mais próximas das reduções jesuíticas e eram vigiadas por índios. Obstáculos naturais como cachoeiras e florestas constituíam as fronteiras das estancias, que funcionavam no sistema open-range. Somente vacas leiteiras e bezerros eram mantidos em currais nas colônias. A principal fonte de renda das 'estancias' era a venda de cabeças de gado (VALVERDE, 1956, p. 88-89).

A pecuária das estâncias das reduções não era ameaçada somente pelos ladrões de gado espanhóis vindos da bacia do Prata, mas também pelos índios nômades Minuanos e Charruas das pradarias, resistentes à cristianização, e ainda pelos portugueses que avançavam a partir da fortificação de Laguna para a Campanha. Se primeiramente predominaram o roubo de gado e o comércio de couro, a partir de 1733 luso-brasileiros se estabeleceram na região dos Campos de Viamão, localizada próximo ao litoral, e fundaram fazendas de gado próprias.

Já na primeira metade do século XVIII, paulistanos tinham saído à procura de novas áreas de pastagem saindo dos 'Campos cerrados' perto de Sorocaba e Itapetininga em São Paulo em direção sudoeste. Lá chegaram aos 'Campos limpos', localizados próximo a Itapeva, os quais tinham forma de arco e se seguiam ao segundo planalto no leste do Paraná, cuja extensão propiciava as linhas mestras para a continuidade da expansão em direção ao Sul.

A 'corrida do ouro' nas Minas Gerais trouxe por volta de 1700 um intenso fluxo migratório para o até então despovoado interior da antiga Capitania de São Paulo e Minas de Ouro, que foi dividida em 1720 em duas partes autônomas. Problemas de abastecimento que acometiam as regiões de Minas Gerais distantes do litoral, bem como os graves problemas de transporte para o litoral de São Paulo e do Rio de Janeiro, levaram a uma valorização econômica dos 'Campos' das regiões elevadas do Paraná e ao desenvolvimento de relações de troca econômica com o sul.

Os rebanhos das vastas 'estancias' de 'Vacaria do Mar' bem como da 'Vacaria dos Pinhais' surgida no início do século XVIII nas regiões altas no leste do Rio Grande do Sul, isolada como uma ilha e por isso segura contra exploração na região de fronteira (PFEIFER, 1967, p. 173) ${ }^{68}$ - possibilitavam o fornecimento de carne dos grandes centros em São Paulo e Minas Gerais. Mais importante, contudo, era a necessidade de animais de carga para o transporte de mercadorias pela Serra do Mar e pela Serra da Mantiqueira, partindo de Santos ou do Rio para Minas e retornando com a valiosa carga de ouro. As únicas regiões de criação de mulas no século XVIII eram, devido a uma proibição de criação aplicada a todas as capitanias (MACHADO; BALHANA, 1963, p. 17), o oeste e o sudoeste do Rio Grande do Sul, que podiam fornecer os animais de carga tão necessitados.

Assim, o principal problema que se configurou foi o estabelecimento de uma via de transporte primitiva, um caminho de condução de gado a partir dos 'Campos' do Sul até as regiões mercantes em São Paulo. O capitão-mor de São Paulo determinou em 1730 que se construísse uma via atravessando as áreas de floresta (MACHADO; BALHANA, 1963, p. 17).

Esse caminho de gado passava pelas florestas de araucárias do planalto, aproveitando habilmente as ilhas naturais dos 'Campos' muito bem distribuídas desde a 'Vacaria dos Pinhais' até Curitiba e

67 Além das 'estancias' das sete colônias missionárias a leste do Rio Uruguai (a norte do Jacuí: Estancia San Luis; ao sul do Jacuí e de leste a oeste do Ibicuí: Estancia S. Lorenzo, S. Juan, S. Miguel, S. Nicolás, S. Borja e S. Angel), permaneceram também na Campanha riograndense as 'estancias' das reduções restantes na margem oeste do Uruguai, La Cruz e Santo Tomás (ao norte do Ibicuí), bem como as de Concepción e Yapeyú (ao sul do Ibicuí). Ao mesmo tempo, Yapeyú, a maior 'estancia', incorporou mais uma parte do atual norte do Uruguai. A pecuária das reduções localizadas a leste do rio Uruguai compreendia em 1768, ano da expulsão dos jesuítas, 178.000 cabeças de gado, 5800 mulas, 7800 jumentos, 22.700 cavalos e mais de 110.000 ovelhas e cabras (segundo números em HERNÁNDEZ, 1913, I, p. 544ss. bem como em mapa nessa publicação; reimpressão em GARSCH, 1934, n. 3).

68 'Vacaria dos Pinhais' ficava fora do alcance dos ataques espanhóis. 
depois até Sorocaba, o maior mercado de jumentos e mulas do Brasil. ${ }^{69}$ A ligação das áreas de pastagem natural de terras altas do Rio Grande do Sul com a planície era feita primeiramente por um caminho de mulas que levava até Araranguá, localizada no litoral catarinense. Dali se chegava ao centro comercial mais importante do Rio Grande: Viamão, fundada em 1725 e localizada na região da atual Porto Alegre. ${ }^{70}$ Algumas décadas mais tarde surgiu uma ligação direta entre Viamão e Vacaria - um ponto intermediário surgido em 1760 no planalto - passando pela floresta subtropical da encosta (WAIBEL, 1955a, p. 38).

Ao longo do caminho de gado, pelo qual, além de jumentos e mulas, também eram conduzidos para o Norte grandes rebanhos de gado, surgiram outras pequenas colônias intermediárias nos locais de parada do rebanho, como a importante Lages e Curitibanos (nos 'campos' elevados catarinenses), Lapa, Palmeira, Ponta Grossa, Castro e Jaguariaíva (na região do Segundo Planalto) e também Curitiba (na região do planalto cristalino).

Entre 1750 e 1800, criadores de gado paulistanos tomaram posse das estepes da região Leste do Planalto Meridional. A economia de pecuária extensiva dos 'Campos Gerais' do atual Paraná estava nas mãos de alguns poucos latifundiários cujos tocadores de gado nas áreas de campo aberto tinham registrado - para seus patrões residentes em São Paulo, São Vicente ou Paranaguá - direitos de propriedade relativos a 'sesmarias' com áreas entre 4.000 e 8.000 alqueires. ${ }^{71}$

Em 1772 havia 29 grandes fazendas de gado na porção Norte dos 'Campos' paranaenses, 12 na porção central e 9 na porção Sul perto da Lapa. Em oposição a essas 50 'sesmarias' que dominavam a criação de gado e o fornecimento para os mercados de São Paulo, Minas Gerais e Rio de Janeiro, havia 125 propriedades menores ao longo do caminho de condução de gado entre Curitiba e Sorocaba (WESTPHALEN; MACHADO; BALHANA, 1968, p. 8-9).

Se a princípio menos de um quinto dos grandes fazendeiros moravam em suas propriedades, no início do século XIX a maioria dos latifundiários tinham residência em suas fazendas, e iam para os locais de acampamento mais próximos somente nos meses de inverno.

A condução de gado iniciada no Rio Grande do Sul em setembro/outubro se valia das boas pastagens durante a época de chuva no seu caminho até São Paulo. Os rebanhos, que em parte vinham também do Uruguai e da Argentina, descansavam nos abundantes pastos do Planalto do Paraná, e alcançavam os mercados de Sorocaba entre janeiro e março, dependendo das condições do tempo. A tomada espontânea de terras nos 'Campos' pelos paulistanos trouxe uma boa fonte de renda por meio do arrendamento das pastagens naturais para as 'tropas' do Rio Grande. Logo as 'invernadas' arrendadas sobrepujaram as pastagens para a pecuária própria. Com a apropriação dos 'Campos' do Terceiro Planalto perto de Guarapuava e de Palmas, realizada a partir de São Paulo, foi aberto um segundo caminho de gado importante até as pastagens do Norte e do Noroeste do Rio Grande, onde especialmente a região das Missões tornou-se famosa pela criação de gado e de mulas. Os dois caminhos convergiam nos 'Campos Gerais' do Paraná. ${ }^{72}$

Os fazendeiros de gado do Paraná, em grande parte a primeira ou a segunda geração de descendentes de imigrantes portugueses, criaram uma estrutura de poder feudal com seus latifúndios geridos extensivamente que, mais tarde, fundamentou a posição social mais elevada de seu grupo social. ${ }^{73} \mathrm{~A}$ prestação de serviços era feita por escravos, em sua maioria negros, mas também índios Botocudos e Coroados capturados. Os primeiros sinais de uma classe média viam-se nos chamados 'camaradas' que, apesar de serem cidadãos livres, agiam como supervisores ou atuavam na milícia privada do fazendeiro de maneira completamente dependente deste. Depois da independência do Brasil e da constituição da

69 Como centro do mercado de animais de carga, Sorocaba desempenhava, na região colonial portuguesa, a mesma função que Salta (atualmente na Argentina) desempenhava para o império colonial espanhol na América do Sul.

70 São conhecidos vários trechos parciais e ligações cruzadas desses caminhos de condução de gado: Viamão - Laguna - Lages - Sorocaba; a Estrada do "Convento" de Araranguá em aclive acentuado em direção a Lages (VALVERDE, 1956, p. 99) e uma ligação entre Lages e Desterro, hoje Florianópolis (cf. a esse respeito KOHLHEPP, 1966a, p. 220-221).

711 alqueire paulista $=2,42$ ha.

72 Na década de 1850 chegou-se ao ponto alto do comércio de mulas em Sorocaba. Entre 1855 e 1860, pastavam anualmente 100.000 mulas e jumentos nas fazendas do Paraná ao passarem pelo caminho até Sorocaba (cf. a esse respeito MACHADO e BALHANA, 1963, p. 18).

73 Saint-Hilaire (1851) menciona mesmo assim o baixo grau de instrução da maior parte dos fazendeiros iletrados que notou em sua viagem de 1820, bem como as suas relações com os 'peões', que praticamente correspondiam às de uma sociedade sem classes e patriarcal. 
província do Paraná em 1853, os grandes fazendeiros dos ‘Campos Gerais’ exerceram influência decisiva em posições de liderança no decorrer dos desenvolvimentos políticos do estado.

A percepção de interesses políticos e comerciais nas cidades e a crescente ausência dos fazendeiros de gado de suas propriedades daí decorrente levou a uma decadência da pecuária extensiva nos 'Campos' paranaenses a partir da segunda metade do século XIX. Se o arrendamento de pastagens de engorda para os rebanhos que estavam de passagem fez com que a iniciativa própria dos donos de terra diminuísse devido a oportunidades de ganho mais fácil, a pecuária declinou ainda mais depois do final do boom de mineração em Minas Gerais e depois da criação de possibilidades de suprimento próprias e próximas aos mercados de São Paulo e do Rio. O mercado de mulas chegou quase totalmente ao fim no final do século XIX, e os escravos libertos se mudaram para as cidades.

Enquanto a vida econômica nos 'Campos Gerais' do Paraná estagnava, dois novos ciclos econômicos - a extração do chá mate ${ }^{74}$ e a exploração madeireira intensificada a partir de $1880^{75}$ - se tornaram muito significativos, o que deslocou o centro econômico para a região das florestas de araucárias do Paraná. Contudo, a expansão partindo do leste para o oeste sobre o Terceiro Planalto só se deu aos poucos. ${ }^{76}$

Em oposição à apropriação total dos 'Campos' do leste por latifundiários luso-brasileiros individuais, havia a exploração primitiva das florestas de araucárias e das florestas subtropicais próximas ao rio Paraná a sudoeste, conduzida por grandes grupos internacionais, bem como posteriormente também por companhias estrangeiras, sobretudo inglesas e argentinas, como a Compañía Maderas del Alto Paraná ou a Companhia Matte Laranjeiras. As concessões de terra que foram fornecidas a essas empresas estavam geralmente condicionadas à colonização e à ocupação da área concedida. Contudo, essas condições não foram satisfeitas, pois, entre outras coisas, a revolução de 1924 e a marcha da Coluna Prestes também trouxeram muita destruição para a região entre Guaíra e Foz do Iguaçu. As companhias se dedicaram principalmente à extração mais lucrativa possível dos produtos dedicados ao mercado, erva-mate e madeira, no menor tempo possível. A estrutura social do Paraná era marcada pelo sistema feudal da economia pecuarista, na qual geralmente os 'peões' viviam em condições tão miseráveis quanto os lenhadores e coletores de erva-mate brasileiros e paraguaios que trabalhavam nas empresas comerciais financeiramente sólidas.

Na primeira metade do século XIX iniciou-se a colonização planejada com imigrantes europeus, e com os 'colonos' introduziu-se uma nova fase de desenvolvimento no Paraná com relação à estrutura econômica e social.

Se as primeiras colônias (por exemplo, Rio Negro, fundada em 1829$)^{77}$ ainda eram fundadas na orla das matas com o intuito estratégico de garantir a segurança das vias de ligação contra ataques de índios, a partir da década de 1870 iniciou-se a exploração controlada das florestas mistas do Primeiro e Segundo Planaltos, bem como o assentamento na região de fronteira entre a mata e os 'Campos' (BIGG-WITHER, 1878).

Apesar de a província do Paraná - separada de São Paulo em 1853 - ter sido a primeira província brasileira a emitir, em 1854, uma lei estadual de sublocação de propriedades para fins de colonização, ${ }^{78}$ a colonização agrária dirigida começou a funcionar muito lentamente, e se restringiu primeiramente à região de Curitiba no planalto cristalino coberto de florestas, onde colonos alemães e poloneses passaram a garantir o fornecimento de alimentos básicos à cidade depois de 1860.

Os alemães do Volga, que chegaram ao Paraná no final dos anos 1870, tiveram logo de abandonar sua meta econômica de cultivar trigo nos solos arenosos e pobres de nutrientes das estepes do Segundo Planalto, formado a partir de sedimentos paleozoicos. Enquanto a maior parte dos colonos voltou a migrar, aqueles que permaneceram mudaram para a prática da coivara na floresta próxima

74 Como o suprimento de mate dos mercados de Buenos Aires e de Montevidéu se tornou impraticável devido à Guerra do Paraguai, a extração de mate do Paraná tomou o lugar dos antigos fornecedores paraguaios.

75 Com o término da construção da Estrada da Graciosa entre Curitiba e Antonina em 1873 e com a ligação ferroviária CuritibaParanaguá, possibilitou-se a exportação de madeira de araucária.

76 Sobre a história do Paraná, cf. entre outros: Fugmann (1929); Figueiredo (1937); Oliveira Vianna (1938); Martins (1939); Machado (1952); Centenário Paraná (1953); Balhana (1955); Valverde (1956); IBGE (1959); Prado (1962); Vianna (1963); ElKhatib (1969); e IBGE (1968, II).

77 O lugar recebeu o nome de Capella da Estrada da Matta e surgiu no local onde o caminho de gado Sul-Norte entrava para a 'Mata do Sertão' (MARTINS, 1941, p. 59).

78 A primeira colônia, Assungui, na região do curso superior do profundo Vale do Ribeira, foi um fracasso devido a uma escolha infeliz de localização, altos preços de terras e péssima organização (WAIBEL, 1955a, p. 85-86). 
a Ponta Grossa, Palmeira e Imbituva. A ocupação, que no Paraná ainda tinha ficado restrita quase que exclusivamente aos 'Campos Limpos' em meados do século XIX, deslocou seu foco de atenção, a partir de então, definitivamente para as amplas regiões de florestas, no que somente as florestas inteiramente de araucárias eram evitadas, devido ao seu solo infértil. A construção da ferrovia que avançava a sudoeste deu, no início do século XX, um impulso para a colonização da floresta por colonos.

Tanto os latifundiários luso-brasileiros com muito capital e pecuária extensiva sobre os 'Campos', quanto os imigrantes do Centro e do Leste europeu - que praticavam a agricultura de coivara em pequenas propriedades nas regiões de florestas - , constituíam dois grupos sociais contrários, cada um com seus objetivos e espírito comerciais diferentes, cujos confrontos levantam problemas até hoje (KOHLHEPP, 1969, p. 151-152). Com isso, os colonizadores da floresta, isolados, iletrados e desorganizados, jamais poderiam concorrer com os clãs de criadores de gado que dominavam a política, cuja hegemonia só foi abalada por volta da virada do século por exportadores de mate e por madeireiros enriquecidos.

A oposição dos latifundiários no Paraná contra a imigração de europeus - numericamente superior aos grupos tradicionais da população - e a ausência dos imigrantes alemães após 1859 como consequência do édito de Heydt, foram as causas para o baixo contingente de imigrantes entre 1853 e 1889: somente 19.000 pessoas. Em um momento em que - depois da proclamação da república - a quantidade de imigrantes sobretudo italianos e espanhóis em São Paulo superava a marca de 100.000 pessoas por ano (1891), no Paraná a população total era de 149.000 pessoas!

Enquanto o cultivo de café atingia seu primeiro ápice no estado de São Paulo, iniciaram-se, com o estabelecimento de alguns fazendeiros vindos de Minas Gerais e São Paulo no Norte Velho do Paraná, os primórdios de uma exploração das florestas tropicais, que se mostraria extensiva 50 anos mais tarde, e que se realizou desde o Norte Velho do Paraná até o rio Tibagi, ainda seguindo o modelo tradicional de plantações.

A expansão dos cafeicultores paulistas trouxe a quinta fase de exploração do Paraná, no âmbito da expansão para o sul vinda de São Paulo, depois das expedições dos bandeirantes no séc. XVII, da ocupação de posições costeiras estrategicamente importantes na mesma época, da apropriação dos 'Campos limpos' do Planalto por parte de criadores de gado no séc. XVIII e da colonização das florestas por pequenos camponeses no leste do estado, iniciada no século XIX.

\section{RELAÇÕES DE POSSE DE TERRA NA ZONA PIONEIRA A OESTE DO RIO TIBAGI NO INÍCIO DA EXPLORAÇÃO MODERNA DO NORTE DO PARANÁ}

As relações de posse nas áreas de floresta tropical e subtropical não-ocupadas no Norte do Paraná se igualavam, em sua opacidade no início da colonização agrária na década de 1920, à situação relativa ao direito de propriedade confusa e já conhecida de outras partes do Brasil.

Com a declaração da independência do Brasil em 1822, tornara-se impossível a nova aquisição de sesmarias, contudo o que dominava era a simples ocupação de propriedades que só veio a ser proibida em 1851. Na mesma época ocorreu a cobrança de todas as concessões de terra que não tinham sido valorizadas pelo cultivo de produtos agrícolas e pela residência fixa dos donos nas propriedades. Uma nova lei de posse de terras definiu a compra como sendo o único método válido para aquisição de terras. Somente o governo imperial poderia dar concessões de terra para a fundação de colônias.

Em 1889, pouco tempo depois da proclamação da república, foi cedida uma concessão de terras de vários milhares de $\mathrm{km}^{2}$ à companhia Estrada de Ferro São Paulo-Rio Grande, sob a condição de que se realizasse a colonização em ambos os lados da ferrovia a ser construída no noroeste e no oeste do Paraná. A partir de 1891, as terras desocupadas passavam a ser da competência de cada estado da federação (WESTPHALEN; Machado; BALHANA, 1968, p. 12). Depois disso, iniciou-se um novo período de concessão de terras, concedidas frequentemente a aliados políticos dos partidos que estavam no poder.

A Revolução de 1930 trouxe a revogação de várias concessões de terras que não tinham preenchido as condições legais dentro do prazo de 5 anos. As terras concedidas à Estrada de Ferro São PauloRio Grande - uma filial da Brazilian Railway Co. - foram devolvidas ao estado do Paraná, já que a 
construção da ferrovia tinha se realizado nesse ínterim para o extremo leste do estado e a colonização das regiões ocidentais não tinha sido realizada pela companhia ferroviária.

Contudo, foi extremamente difícil a luta da colonização dirigida privada e pública contra os chamados 'grileiros'. Esses especuladores de terras, em geral residentes nas cidades e politicamente influentes, tinham tomado posse de enormes áreas de terra ('grilos') por meio de concessões de terra duvidosas, transferências falsificadas e títulos de propriedade em geral falsos. Dessa maneira, já no início da real colonização no norte do estado foram reivindicados por grileiros cerca de $55.000 \mathrm{~km}^{2}$ de área florestal não-ocupada, ou seja, mais de um quarto de toda a área do estado. Os 'grilos' compreendiam, em geral, várias dezenas de hectares, e as reivindicações de propriedade totalizavam áreas de mais de 1 milhão de hectares, como se pode depreender do Mapa 9 e da Tabela 2 abaixo:

Tabela 2: Os maiores grilos do Norte do Paraná em extensão de terra ${ }^{79}$

\begin{tabular}{l|c|}
\hline 1. Reconquista & 1.080 .000 \\
\hline 2. Bandeirantes & 977.100 \\
\hline 3. Pirapó & 894.400 \\
\hline 4. Boa Esperança & 619.500 \\
\hline 5. Corumbataí & 523.400 \\
\hline 6. Guavirova & 413.800 \\
\hline 7. Barra do Tibagi & 358.900 \\
\hline 8. Ubá & 242.000 \\
\hline 9. São Manuel & 171.800 \\
\hline 10. Ribeirão Vermelho & 108.900 \\
\hline 11. Tigre & 42.700 \\
\hline 12. Barra Bonita & 39.400 \\
& 5.471 .900 ha
\end{tabular}

Área em ha

.471 .900 ha

As práticas dos grileiros estiveram quase sempre ligadas a tomadas de posse controladas por eles frequentemente violentas e ilegais - e que eram levadas a cabo pelos chamados 'intrusos', introduzidos para assegurar as reivindicações de direito de propriedade. Tanto para se opor às legítimas pretensões de posse de terra das companhias colonizadoras particulares - que tinham comprado a terra do governo do estado de maneira correta -, quanto para se opor aos representantes dos órgãos do poder executivo, os grileiros fizeram uso frequente de milícias privadas próprias ${ }^{80}$, tanto no Paraná quanto em outras áreas do Sudeste e do Nordeste brasileiro. Confrontos violentos marcam tanto o avanço para oeste da fronteira no norte do Paraná quanto o movimento migratório interno sul-norte vindo do Rio Grande para o sudoeste do Paraná. ${ }^{81}$

A colonização agrária que se iniciava foi dificultada, além do movimento controlado dos 'intrusos', também pela tomada de posse espontânea de terras devolutas ou que já tinham sido vendidas mas ainda não exploradas pelos proprietários, por parte de 'intrusos' individuais ou de grupos de tais ocupantes [squatter].

79 Segundo o Relatório da Interventoria Federal do Paraná ao Presidente da República, relativamente ao período de 1932 a 1944 (p. $24-26$ e Mapa 1). Recálculo das extensões de terra realizado segundo Westphalen et al. (1968, p. 24-25).

80 Chamados de jagunços, capangas ou também pistoleiros.

81 Cf. sobre isso El-Khatib (1969); Martins (1939) e notícias em jornais diários paranaenses. 
Para se avaliar as relações de direito de posse nas regiões pioneiras do Paraná, deve-se diferenciar a atividade e a motivação de dois grupos de ocupantes:

a) Os 'intrusos' não estão interessados na legalização de suas 'posses', mas sim em uma exploração delas a curto prazo. Eles se aproveitam do objetivo do proprietário legal que quer cultivar sua terra, porém só saem por vontade própria das terras ocupadas por eles quando há uma compensação financeira, e imediatamente depois disso voltam a exercer essa prática em outro lugar (WESTPHALEN; MACHADO; BALHANA, 1968, p. 22-23).

b) Em oposição à mobilidade dos 'intrusos', os 'posseiros' anseiam por estabilidade e não têm interesses especulativos. São famílias sem terra ou grupos de famílias que se estabelecem em terras não-ocupadas ou que não foram cultivadas pelo proprietário. Elas estabelecem sua morada fixa e praticam primeiramente agricultura de subsistência, mas objetivam com frequência passarem a um produto de mercado com o progresso da colonização e o desenvolvimento da infraestrutura. Os 'posseiros' desejam obter o título de posse da terra cultivada por eles.

A especulaçãofundiária feita pelos grileiros, quecom frequência apresentavam suas reivindicações de posse somente depois de iniciada a exploração e depois da consequente valorização da terra, adiantou-se ao avanço da frente pioneira. Suas atividades criminosas se dirigiam principalmente contra os posseiros, cuja força de trabalho prometia muitos ganhos principalmente antes da realização da colheita. Tanto o confronto dos grileiros, posseiros e intrusos entre si, bem como entre eles e a colonização dirigida privada e estatal, por motivos jurídicos e morais, são característicos da região de fronteira no Brasil.

Porém, uma vez que a colonização do Norte Novo do Paraná começou no início da década de 1930 - uma época em que a crise cafeeira e a crise econômica mundial alcançavam seus ápices e em que a economia cafeeira não podia contar com uma área grande de cultivo no norte do Paraná por causa da forte geada de 1918 nas regiões sul e oeste de São Paulo - , a primeira fase dessa colonização se diferencia da que se deu no oeste de São Paulo.

Nessas regiões, clãs familiares poderosos controlavam, com auxílio de seus 'capangas', a concessão de terras durante a expansão do cultivo do café. No Norte do Paraná, as disputas de posses só tomaram formas mais sérias com a revalorização das terras ocorrida no boom cafeeiro que se iniciou na década de 1950, principalmente nas regiões em que se realizava a venda de terras pelo estado. ${ }^{82}$

As formas da colonização dirigida privada e da colonização controlada estatal no norte do Paraná apresentam grandes diferenças em sua concepção, plano de desenvolvimento e na realização de projetos de assentamento individuais, cujos impactos sobre a exploração agrária como um todo serão analisados a seguir.

\section{O SIGNIFICADO DA COLONIZAÇÃO DIRIGIDA PRIVADA PARA O DESENVOLVIMENTO DO NORTE DO PARANÁ DESDE 1930}

\section{a) A Companhia de Terras Norte do Paraná: Modelo de planejamento regional na fronteira do assentamento}

A contribuição mais significativa para a exploração e para o desenvolvimento econômico do Norte do Paraná foi feita por uma companhia colonizadora inglesa de iniciativa privada ${ }^{83} \mathrm{O}$ fundador dessa companhia foi Lord Lovat, ${ }^{84}$ um escocês especialista em agricultura, reflorestamento e problemas de colonização. Em 1924, ele estudou, juntamente com a Comissão Montagu a convite do governo brasileiro, possibilidades para o desenvolvimento econômico em diferentes regiões do

82 Sobre as condições subjacentes a esse problema, ver Cap. III, 5.

83 Sou grato de maneira especial às seguintes pessoas (entre muitas outras) por diversas discussões sobre a atividade colonizatória da CTNP, bem como por comunicações pessoais e pela ajuda na exploração do material de arquivo e de demais fontes: Dr. C. Vidigal, G. Fox Rule, B. Kiiswerk (São Paulo), A. de Souza Melo (Londrina), A. W. Nieffeler, Dr. W. Babkov e A. Bianchini da Rocha (Maringá).

84 Simon Joseph Fraser; cf. sobre isso Lindley (1935). 
país - principalmente tendo em vista o cultivo do algodão e o fornecimento de matéria-prima à indústria têxtil inglesa - , e também visitou o nordeste do Paraná no ponto final da Ferrovia Sorocabana, na região de Cambará.

A intenção original da Brazil Plantations Syndicate Ltd. - fundada por um grupo inglês financeiramente sólido ainda no ano de 1924 em Londres por iniciativa de Lovat - de investir em extensas plantações de algodão com base nas experiências adquiridas no Egito e no Sudão anglo-egípcio (o 'Projeto Gezira') falhou devido a maus resultados de experimentos. Após estimativas corretas do potencial natural das áreas de 'terra roxa' do norte do Paraná, foram fundadas em 1925 duas novas companhias pelo mesmo grupo, que tinham como objetivo um grande projeto de colonização com base em pequenas e médias propriedades:

a) A Paraná Plantations Ltd., com sede em Londres, que assumiu todo o finaciamento. ${ }^{85}$

b) A 'Companhia de Terras Norte do Paraná' (CTNP), com sede em São Paulo e com a tarefa de operar a compra de terras, conduzir a exploração da terra e recrutar colonos.

Ao contrário do que fazia a maioria das companhias colonizadoras privadas em atividade no Brasil, os preparativos para esse projeto - que se estenderam por 5 anos - foram conduzidos com os maiores cuidados, e a venda das terras se iniciou somente em 1930. A coordenação foi assumida por um especialista em colonização escocês que atuou anteriormente no Sudão e que combinava experiência em agricultura tropical e subtropical com talento organizacional e dom de negociação.

Contudo, a companhia colonizadora auferiu seu maior mérito por meio de sua sólida política de aquisição e posterior venda de terras. Até o ano de 1928, a CTNP já tinha obtido cerca de $12.500 \mathrm{~km}^{2}$ de área de florestas na região ao sul do rio Paranapanema e a oeste do rio Tibagi, ${ }^{86}$ uma região que se estendia para além do rio Ivaí (Mapa 10) e era composta na sua maior parte por uma área livre de malária com altitudes entre 500 e $875 \mathrm{~m}$. A resolução das questões de propriedade e a obtenção dos títulos de propriedade das terras compradas se configurava uma tarefa especialmente difícil em uma região com forte especulação fundiária e permanentes disputas pela posse das terras. Dentro de um prazo especificado e com apoio do então governador Munhoz da Rocha, foram adquiridas todas as reivindicações de direito de posse - seja de antigas concessões de terra ou de compras de terras - , tanto de grileiros, intrusos e posseiros quanto do estado do Paraná. Assim, tanto reivindicações legais quanto títulos falsificados de posse foram comprados, compensações foram dadas a intrusos e a posseiros, e por alguns terrenos chegou-se a pagar cinco vezes seguidas. Esse método era o único que podia ser utilizado na frente pioneira do Brasil, e com isso todos os direitos de propriedade foram passados à CTNP antes do início da valorização das terras. O baixo preço das terras - cerca de US\$ 2 por alqueire paulista (= 2,42 ha) - permitiu que a Companhia comprasse todos os direitos de propriedade com um encargo financeiro total quase dobrado.

Em 1944, durante a II Guerra Mundial, a britânica Cia. de Terras Norte do Paraná foi vendida, no âmbito do financiamento de guerra, a um grupo brasileiro de empreendedores ${ }^{87}$, que comprou no mesmo ano a gleba Cruzeiro (com $725 \mathrm{~km}^{2}$ ) no Norte Novíssimo, que já tinha sido agrimensada e devolvida ao estado do Paraná devido a conflitos pela posse. ${ }^{88}$ A companhia colonizadora brasileira obteve em 1951 o nome de 'Companhia Melhoramentos Norte do Paraná' (CMNP). Durante a operação imobiliária, o governo brasileiro insistiu na transferência da linha férrea construída pela companhia, que teve que ser vendida para a União. A péssima condição financeira do estado e a organização insuficiente fizeram com que se postergasse o seguimento da construção da ferrovia. Por outro lado, os trabalhos de exploração

85 O capital inicial de $£ 750.000$ foi posteriormente aumentado para $£ 1.85$ milhões (SCHAUFF, 1957b, p. 35).

86 Em 1925 foi realizada a compra de uma gleba de 350.000 alqueires juntamente com a concessão da construção da ferrovia pela Cia. Marcondes de Colon., Ind. e Com., bem como de uma área de 100.000 alqueires da propriedade de Dr. Coelho de Almeida. Entre 1926 e 1928 foram obtidos os títulos de posse de 3 áreas de terra, com 30.000 (Concessão de Alves de Almeida), 20.000 (Francisco Beltrão) e 15.000 alqueires (Cia. Tibagi Ltda.) respectivamente, totalizando 515.000 alqueires $=12.463 \mathrm{~km}^{2}$ (VIDIGAL, 1970, p. 123-24).

87 As negociações se estenderam por 5 anos. O grupo foi liderado por brasileiros que tinham cargos chave na CTNP (engenheiros, consultores jurídicos) e que se ligaram a banqueiros de São Paulo e Rio de Janeiro. Cf. sobre isso Thomas (1949); Barrros (1953); e Vidigal (1970).

88 Por razões políticas, a gleba Cruzeiro estava separada das demais terras da CTNP. Nesse espaço se localizava a colônia estatal de Cruzeiro do Oeste, cuja localização de fronteira oferecia vantagens de proximidade. A medição realizada pelo governo foi totalmente assistemática, e as propriedades eram blocos de, em média, mais de 200 ha. A CTNP teve que realizar novas medições sob condições adversas, e optou aqui também pelo sistema de lotes da divisora de águas ('espigão') para o curso da água. 
da nova companhia foram continuados sob o comando do antigo chefe de projeto inglês segundo o mesmo sistema.

Além da agrimensura exemplar e da garantia também exemplar dos títulos de posse dos compradores posteriores, o desenvolvimento do transporte recebeu atenção especial na região de colonização. Primeiramente, tratava-se da acessibilidade das terras a Oeste do rio Tibagi, que - apesar de estarem no estado do Paraná - recebiam impulsos de exploração e ocupação quase que exclusivamente de São Paulo.

O plano de uma ligação ferroviária de Presidente Prudente à ferrovia Sorocabana em direção sul até o rio Paranapanema - para onde já havia sido traçado um caminho vindo do sul até a região do rio Pirapó - foi novamente descartado, já que o arenito Caiuá se sobrepunha às capas vulcânicas nas divisoras de águas dispostas em forma de platô e localizadas entre os afluentes do Paranapanema, o que ocasionava a ausência do tão esperado solo fértil de 'terra roxa' (MAACK, 1937, p. 232).

Assim, tomou-se a decisão de avançar a linha férrea para oeste, em rota direta de impacto com a expansão paulistana sobre o terceiro planalto do Paraná, na região dos solos de decomposição vulcânica. Um ramal ferroviário já existente, que fora instalado por proprietários de cafezais vindos de São Paulo no extremo nordeste do Norte Velho e que se estendia de Ourinhos até Cambará $(29 \mathrm{~km})$, serviu de ponto de partida. Em 1928, a CTNP obteve a maioria das ações dessa linha férrea; em 1929 retomou a construção dela, e dentro de 3 anos criou uma ligação ferroviária até o rio Tibagi que foi ampliada em 1935 até Londrina.

A colonização interna dos $12.500 \mathrm{~km}^{2}$ da área de assentamento foi levada a cabo segundo um plano previamente concebido. A construção das estradas de acesso pelas divisoras de águas antecedeu a venda das terras. Estradas de 4 a $5 \mathrm{~m}$ de largura rodáveis o ano todo, providas tanto de caminhos laterais quanto de pistas de vistoria foram construídas de maneira sistemática, de forma que todo terreno vendido tivesse ligação com a malha viária.

A venda das terras começou no ano de 1930 em Londrina, a primeira base principal da companhia e o ponto de partida para a exploração. A área total foi dividida em 6 zonas, e estas por sua vez desmembradas nas chamadas 'glebas'. A venda de terras, comprometida claramente com as melhores condições possíveis, ${ }^{89}$ foi feita na forma de pequenas e médias propriedades, em que a área dos terrenos vendidos nos primeiros 10 anos era de, em média, 40 hectares.

A motivação para a agrimensura dos lotes era o desejo da companhia colonizadora de garantir a todos os compradores de terra tanto uma ligação viária para as estradas de rodagem, que passavam pelas cumeeiras das divisoras de águas, quanto o acesso à água. A distribuição em forma de faixas dos lotes retangulares, desde a divisora de águas até o fundo do vale, facilitava - dum ponto de vista organizacional - a agrimensura e a avaliação dos terrenos, e deu a todos os colonos partes iguais às unidades com grandes diferenças naturais entre si, devidas a fatores microclimáticos e pedológicos. A forma de divisão de terras que se firmou - lotes em faixas largas no sistema Waldhufen (Mapa 10a) - é uma adaptação às condições naturais do terreno (que permitiam uma divisão sistemática ${ }^{90}$ ) e não resulta de normas de agrimensura ditadas pelo governo ${ }^{91}$ (Fotos 2 e 5). Contudo, não se pode esquecer que alguns dos agrimensores ativos no norte do Paraná vinham da Alemanha, já tinham feito algumas medições de terra no sul do Brasil e por isso estavam familiarizados com as formas de divisão de terras no sistema Waldhufen.

89 O preço de compra por hectare corria inicialmente entre US\$ 7 e US\$ 8 por hectare, em Rolândia chegava a US\$ 16. Condições de pagamento diferenciadas de acordo com a distância centro-periferia e com o tamanho das áreas tinham por objetivo permitir a exploração simultânea mesmo dos lotes mais distantes dos assentamentos, mediante um adiantamento de $30 \%$ do preço do lote e pagamento do restante parcelado em 4 anos. Para pequenos lotes próximos da cidade, o adiantamento era de $40 \%$ e 2 anos para para pagar o restante. Terrenos nos assentamentos urbanos planejados eram concedidos mediante adiantamento de $50 \%$ e um prazo de 1 ano para pagamento do restante do valor. A taxa de juros era de $8 \%$ a.a., um valor extremamente baixo para o Brasil. No caso de inadimplência devido a erros iniciais de gestão, era adiado o pagamento do montante devido por colonos dispostos a trabalhar.

90 Para o Rio Grande do Sul e para Santa Catarina, Waibel (1955a, p. 9) e Smith (1963) admitem o mesmo, apesar de a encosta do Planalto Meridional apresentar diferentes condições morfológicas.

91 Na argentina Misiones, a divisão dos campos segundo o sistema Waldhufen, adaptada ao terreno e à bacia hidrográfica, só se firmou muito lentamente nas regiões montanhosas em contraponto ao sistema ortogonal de dameros, definido pelo governo (WILHELMY, 1949a, p. 25ss.). A nova divisão de terrenos com acesso a água em Misiones teve como resultado o início da atividade pecuária e uma venda mais rápida dos terrenos assim agrimensados (EIDT, 1971, p. 99). 
Contudo, no norte do Paraná não se firmou a forma de assentamentos correspondente à do sistema de aldeias alinhadas, uma vez que as casas e os prédios comerciais, instalados durante o primeiro estágio da colonização à beira dos riachos no fundo dos vales, ${ }^{92}$ foram instaladas na fase seguinte, de expansão interna, colina acima e a cerca de um terço da altitude com relação à fronteira inferior das plantações de café.

As casas dos vilarejos em sistema de Waldhufen - por exemplo, na área de colonização medieval do leste - se alinham por quilômetros em linhas ao longo de estradas e frequentemente dispostas ao longo do curso de um rio. Um "assentamento disperso linear" (WAIBEL, 1955a, p. 92) predomina também em áreas de assentamento de alemães nos estados do Rio Grande do Sul e de Santa Catarina, no sul do Brasil, onde as casas se alinham no fundo do vale, à 'picada', à 'linha colonial' ou à 'raia' dos colonizadores vindos do Hunsrück. Ao contrário, a forma de assentamento que consiste em séries de casas individuais em uma divisão em largas faixas no sistema de Waldhufen ${ }^{93}$ não previu, no norte do Paraná, a ligação dos quintais das casas à estrada; os quintais das casas se dispunham lado a lado na encosta, sem ligação por estrada, mas com ligações transversais até as estradas principais. ${ }^{94}$ As razões para as casas dos colonos e os prédios comerciais se localizarem no terço inferior da encosta são, por um lado, o gradiente do valor do solo desde a cumeeira - reservada exclusivamente para a valiosa lavoura de café - até o fundo do vale, sujeito a geadas e por isso não apropriado para o cultivo do café; por outro, a dificuldade no fornecimento de água ao espigão. Importância secundária tem a ação da poeira, que faz com que uma faixa de 30 a $40 \mathrm{~m}$ para ambos os lados das rodovias não pavimentadas sejam quase inabitáveis. ${ }^{95}$

As dimensões dos terrenos se orientavam pelo tamanho planejado de aprox. 40 ha, de acordo com a profundidade no vale e a distância entre a divisora de águas e o curso do rio.

As faixas tinham originalmente uma largura que variava de 150 a $300 \mathrm{~m}$, e um comprimento entre 1 e $2,5 \mathrm{~km}$ (muito raramente mais do que isso), de forma que a proporção entre largura e comprimento fosse, em geral, entre 1:5 e 1:15. Propriedades maiores - que se encontravam no final do vale ou às margens de rios maiores - eram agrimensadas só muito raramente.

As distâncias entre os lotes individuais são mantidas de tal forma que surge um sentimento de vizinhança, e se torna possível haver ajuda mútua entre os vizinhos em casos de emergência. Em muitos casos duas casas ficam próximas aos limites das propriedades de frente uma à outra, justamente devido à estrada de acesso à estrada principal que ambas compartilhavam. A distância entre as casas individuais fazem, contudo, com que sempre surja o sentimento de propriedade isolada - um fator psicológico extremamente importante para a grande quantidade de antigos trabalhadores rurais e arrendatários que foram a primeira geração a obter terras próprias no norte do Paraná. A disposição espacial das propriedades mostra uma clara estruturação partindo do centro do assentamento em direção à periferia:

1. Na área mais estreita em torno dos assentamentos até aprox. $1 \mathrm{~km}$ de distância eram instaladas 'chácaras', pequenas propriedades de até 1ha que eram vendidas a moradores da cidade e eram previstas para o plantio de árvores frutíferas, hortaliças e pecuária de leite intensiva para cobrir a demanda local. As chácaras constituem o mais interno dos Anéis de Thünen (Mapa 10a).

Em torno de assentamentos urbanos maiores também era planejado um "cinturão verde" que devia ser composto de restos de floresta tropical e de reflorestamentos.

2. Depois destes seguiam os 'sítios', com área de 25 a 50 ha, que compreendiam $90 \%$ dos lotes agrimensados e que eram previstos para o cultivo comercial do café (Fotos 4 e 5).

3. Na área mais retirada, geralmente distante mais de $15 \mathrm{~km}$ e topograficamente mal localizada, eram agrimensadas também 'fazendas' (mais de 200 ha) - frequentemente com grandes reservas de mata - que deveriam se dedicar, entre outras coisas, à pecuária.

92 A localização à margem do curso d'água foi escolhida menos para o suprimento de água do que para os animais domésticos (MONBEIG, 1935, apud MONBEIG, 1945, p. 12).

93 Cf. sobre isso Nitz (1962, p. 79); cf. Nitz (1974) e Kohlhepp (1975), bem como o Mapa 52.

94 Em Misiones também foi feito o desmatamento do curso do rio subindo a encosta até a estrada, no que a casa do colono ficava primeiramente à margem do rio, porém depois era transferida para próximo da estrada. Eidt (1971, p. 101) diferencia como formas de assentamento, além de 3 tipos de 'Waldhufen-like settlements' ('assentamentos no estilo Waldhufen'), vilarejos Waldhufen com funções urbanas centrais de 'Waldhufenweiler' (German-style forest long-lot farm settlements, 'assentamentos em fazendas de longos lotes no estilo alemão') com poucas e parcas funções centrais, ou mesmo nenhuma.

95 Problemas semelhantes são descritos por Eidt (1971, p. 140) para a aldeia Waldhufen de Monte Carlo, em Misiones. 
Na divisão planejada da área, com base em núcleos funcionais, foram criados grandes centros urbanos ao longo dos $100 \mathrm{~km}$ do eixo leste-oeste formado pela ferrovia e pela estrada e que passava pela divisora de águas. Foi o caso de Londrina, Maringá, Cianorte e mais tarde, na recém-obtida gleba Cruzeiro, Umuarama (cf. Mapa 10). Nesse espaço surgiram - também sobre os espigões - pequenos centros urbanos como pontos intermediários das glebas, localizados a cada 12 ou $17 \mathrm{~km}$ ao longo das estradas rodáveis o ano todo (Mapa 10a: Jussara, Terra Boa). Fora das vias de transporte principais e entre os pequenos centros foram criados os chamados 'patrimônios' no sistema de planta ortogonal, locais centrais da classe mais baixa para o suprimento mais básico da população rural (Mapa 10a: Malu; Vidigal) ${ }^{96}$.

O objetivo da CTNP era a criação de uma zona mista de assentamento com elementos colonizadores brasileiros, mas também europeus e japoneses. Os grupos deveriam ser assentados juntos segundo sua nacionalidade, por razões psicológicas. ${ }^{97} \mathrm{~A}$ importância desse fator foi frequentemente subestimada pelos órgãos oficiais brasileiros.

Faziam parte dos serviços prestados pela CTNP o transporte gratuito dos compradores de terras até as suas propriedades, o fornecimento de meios de transporte, e o estabelecimento de esquadrões de derrubada que realizavam o trabalho de desmatamento, algo a que muitos dos novos colonos não estavam habituados. Essa prestação de serviços era compensada parcialmente com a compra de lenha pela Companhia. Os cuidados médicos para os colonos, bem como a construção e a manutenção de escolas, foram realizados de maneira exemplar.

O trabalho da CTNP - o maior e mais bem sucedido projeto de colonização da América do Sul mostra que os maiores sucessos no desenvolvimento regional brasileiro se baseiam nas (infelizmente muito poucas) companhias colonizadoras privadas e financeiramente sólidas, ${ }^{98}$ que tiveram como objetivo o desenvolvimento com garantias de direito de posse de médias e pequenas propriedades e, com isso, a colonização mais intensiva com a construção da infraestrutura necessária e a fundação de pontos urbanos intermediários. Foi somente o trabalho conjunto de companhias colonizadoras e empresas de transporte (linha férrea), uma novidade para o Brasil, que possibilitou um planejamento regional integrado no norte do Paraná.

\section{b) Atividades de pequenas companhias colonizadoras privadas}

A colonização a oeste do rio Tibagi fora iniciada por duas companhias menores ${ }^{99}$ que em 1919 já tinham obtido cada uma 50.000 ha (Mapa 10, n 1 e 2). Desde 1923, as colônias Primeiro de Maio e Sertanópolis foram desenvolvidas com colonizadores de São Paulo que avançavam pelo rio Paranapanema em direção sul.

O objetivo da colonização era a utilização dos férteis solos de 'terra roxa' nas cumeeiras das divisoras de águas. Além das chácaras menores próximas aos centros dos assentamentos, foram agrimensados sítios em faixas largas na direção das encostas, um sistema que foi utilizado mais tarde pela CTNP em larga escala. Fazendas menores, com 300 a 400 ha, foram concedidas especialmente para o cultivo de café em lugares mais altos.

Além disso, os compradores dos lotes da colônia Sertanópolis eram obrigados a erguer, dentro de 2 anos, um prédio no centro do assentamento em um terreno destinado a eles sem custo, o que levou a um rápido desenvolvimento de Sertanópolis - que em 1927 foi elevada a sede do distrito e, em

96 Sobre isso ver Cap. III, 6.

97 Depois de 1938, isso foi proibido com base na nova legislação sobre o assentamento de estrangeiros. Contudo, em oposição a isso, principalmente Waibel (1955a, p. 134-35) ressaltou a importância de uma comunidade linguística, religiosa e cultural para a psique dos imigrantes em um ambiente estranho a eles. A criação de assentamentos com colonos brasileiros e imigrantes de diferentes nacionalidades em vizinhança direta evita temores do surgimento de 'enclaves estrangeiros' de grande extensão. Assentamentos mistos no Paraná - assim como em outras partes do Sul do Brasil - tiveram normalmente um péssimo desenvolvimento, devido à decadência do padrão cultural e econômico dos imigrantes, como p. ex. Cruz Machado e Cândido Abreu (MAACK, 1937, p. 232).

98 No oeste de São Paulo ganhou em importância a Cia. Paulista de Estradas de Ferro, que surgiu como empresa de transportes para aprimoramento do transporte das plantações de café de alguns latifundiários paulistanos, e a partir da qual se desenvolveu - só secundariamente - uma companhia de colonização, a Cia. Agrícola de Imigração e Colonização. A Soc. Colonizadora do Brasil surgiu na propriedade japonesa e era a organização tutelar pra o assentamento de imigrantes japoneses em São Paulo e no nordeste do Paraná. Sua organização tomava conta das áreas econômica, social e cultural dos colonos japoneses (MONBEIG, 1952, p. 217-218).

99 Corain e Co. e, adjacente ao sul, Cia. Paula Vieira. 
1929, à categoria de cidade. ${ }^{100}$ Devido ao relevo acidentado do local nas proximidades dos rios Tibagi e Paranapanema, somente os espigões eram apropriados para o cultivo do café, e já desde cedo a pecuária extensiva se estabeleceu nos fundos de vale.

Algumas outras tentativas colonizatórias privadas que se estenderam do sul do Paranapanema até o Pirapó falharam por razões financeiras e devido ao seu isolamento, e foram devolvidas ao estado do Paraná. ${ }^{101}$ Somente a colônia Zacarias de Góis permaneceu, porém se desenvolveu só muito lentamente (Mapa 10: $\mathrm{n}^{\circ}$ 6).

Grandes fazendeiros paulistas também tinham obtido propriedades na fronteira das terras da CTNP, porém eram somente áreas pequenas; entre estes estava Barbosa Ferraz de Ribeirão Preto, que, para além de sua atividade colonizatória no Norte Velho, mandou colonizar também a Fazenda Ubá entre os rios Ivaí e Corumbataí. ${ }^{102}$

As localidades de Ibiporã e Engenheiro Beltrão são criações privadas do engenheiro Beltrão, que obteve em 1935 concessões de terras do governo na região periférica da CTNP.

Empresas colonizatórias privadas menores vindas do Rio Grande do Sul - sobretudo no noroeste do Paraná - tinham como objetivo o assentamento controlado de colonizadores teuto- e ítalo-brasileiros. Contudo, frequentemente as atividades dessas companhias foram limitadas devido a dificuldades financeiras. ${ }^{103}$ Resultados permanentes com importância regional não puderam ser obtidos por nenhuma dessas empresas menores no norte do Paraná.

\section{COLONIZAÇÃO ESTATAL E POLÍTICA DE VENDA DE TERRAS}

Fora dos limites das terras ocupadas por sociedades privadas de colonização, a ocupação territorial desregrada efetuada por intrusos e posseiros havia tomado grandes proporções já na década de 30, sobretudo na região entre os Rios Piquiri e Ivaí. Caboclos vindos das regiões central e sul do Paraná, bem como os descendentes de imigrantes italianos e poloneses haviam se apossado de vastos territórios em um movimento espontâneo, nos quais utilizavam a agricultura itinerante irregular e, mais raramente, o sistema de rotação de terras (coivara) no cultivo do milho para a engorda de porcos. Extensas regiões florestais foram desmatadas devido a essa prática, antes que a colonização oficial entrasse em vigor.

Em face desse desenvolvimento e no intento de realizar uma exploração controlada nas regiões florestais paranaenses restantes por meio de colonos brasileiros, o governo do Paraná decidiu, em 1939, implantar um programa oficial de colonização.

Surgiram então as colônias Mourão, Goio-Erê, Goio-Bang, Cantú, Piquiri, Muquilão e Manoel Ribas (Mapa 10). Cada uma das glebas das colônias foi subdividida em terrenos de 10-200 ha, em parte na forma de faixas, mas em parte também em blocos irregulares, medindo em média, em sua maioria, mais de 50 ha, e em algumas regiões até mesmo mais de 100 ha.

Contudo, o objetivo dessas medidas - levar os caboclos a assentar-se permanentemente por meio da entrega de títulos de propriedade - foi apenas parcialmente alcançado. Em algumas colônias (Piquiri, Cantú), o número de intrusos excedia o de lotes (BERNARDES, 1953, p. 351ss.) previstos, de modo que uma vigorosa subdivisão teve de ser relizada, o que, no entanto, não foi capaz de evitar que frequentemente mais de uma família intrusa se alojasse em uma mesma propriedade.

100 A partir das fontes não resulta evidente se aqui se havia pensado no estabelecimento dos colonizadores num povoado ou na possibilidade de se disponibilizar ou alugar moradias no local para os recém-chegados ativos no comércio (cf. sobre isso BERNARDES, 1953, p. 362-363).

101 Glebas Nova Bahia e Pirapó em 1934.

102 Obtida em 1929, Companhia colonizadora Soc. Territorial Ubá Ltda. (sócios, entre outros, também G. Lunardelli), porém a venda de terras só se iniciou em 1951 com pequenas propriedades ( 20 ha).

103 Por outro lado, uma companhia fundada em Porto Alegre - Maripá - teve sucessos significativos ao sul do rio Piquiri (fora da região consderada aqui), entre cujas realizações conta a colonização da região em torno de Toledo e General Rondon (cf. sobre isso OISERG e JABINE, 1960, bem como MULLER, 1974). 
Das colônias mencionadas, as que se encontravam ao sul situavam-se em meio à floresta de araucárias e à floresta mista do terceiro planalto, cuja altitude varia entre $650 \mathrm{~m}$ e $1000 \mathrm{~m}$ acima do nível do mar. A ocupação controlada foi severamente dificultada pelas lentas obras de viabialização realizadas por instituições estatais financeiramente debilitadas.

Uma malha viária deficitária, a grande distância dos centros de comércio e a incerteza com relação às condições de posse adiavam o avanço da frente pioneira em direção ao noroeste e ao oeste do estado. Em algumas colônias, a agrimensura definitiva dos terrenos que já haviam sido apossados somente pôde ser efetuada após 1950 (Mapa 10).

Já a colônia Mourão, localizada mais ao Norte, encontrava-se em situação relativamente mais favorável. Ali, a uma altitude entre $400 \mathrm{~m}$ e $650 \mathrm{~m}$, as condições naturais ainda permitiam o cultivo de café ao longo da ligeira inclinação do relevo em direção ao rio Ivaí.

Aqui, bem como nas regiões de colonização estatal situadas ao sul e na região de Faxinal de São Sebastião - localizada na orla do Terceiro Planalto - , como também na região a leste do rio Pirapó e - no extremo noroeste do estado - na colônia Paranavaí, houve inúmeras disputas pela posse da terra, duradouras e em parte violentas.

Muitos dos caboclos abandonavam suas terras após a agrimensura e a obtenção do título de propriedade, deixando de pagar o devido preço de compra e vendendo ou arrendando a terra que ainda não lhes pertencia integralmente para posseiros que os coagiam a isso.

Alguns dos governos subsequentes ao exercício do interventor Ribas complicaram o quadro geral da questão da posse de terra devido a uma política de venda de terras pouco confiável. Colônias de localização privilegiada e com solo de terra roxa foram concedidas a membros do partido e a mediadores fiéis ao governo.

Tiveram grande repercussão a exploração e devastação total das reservas florestais que já haviam sido demarcadas a leste do rio Piquiri, às margens do Corumbataí, bem como no noroeste às margens do Paranapanema (Mapa 10), assim como o desmatamento de extensas faixas de florestas de araucária localizadas nas regiões central e sul do Paraná - ações realizadas especialmente sob o governo de Moisés Lupion.

O papel desempenhado pelo então governador Lupion se esclarece pela sua participação na indústra madeireira (serrarias), no comércio e na exportação de madeira ${ }^{104}$. O Departamento de Geografia, Terras e Colonização, órgão do estado responsável pela colonização estatal, também foi criticado publicamente de maneira muito dura.

Nos anos de 1946 e 1947, os conflitos pela posse de terras na região de Jaguapitã e Porecatu chegaram ao seu apíce em um confronto armado entre cerca de 1500 famílias intrusas e de posseiros e o governo, que se posicionou a favor dos latifundiários daquela região.

Em caso de as famílias se retirarem por livre e espontânea vontade, o governador prometeu a cada uma delas 24 ha de terra e uma casa de madeira, bem como o transporte para os novos assentamentos às margens do rio Paranapanema. Os posseiros e intrusos recolheram suas colheitas, prepararam-se para a transferência e abandonaram suas plantações.

Contudo, o governo estadual não cumpriu sua promessa e os caboclos passaram por dificuldades para se alimentarem durante os meses de inverno. Os posseiros resistiram obstinadamente à polícia militar, posta em ação por causa das decorrentes inquietações (WESTPHALEN; MACHADO; BALHANA, 1968, p. 33).

Inúmeros outros casos semelhantes sublinham a desorganização e especulação, a concessão ilegal de terras a partidários do governo e a falta de boa vontade para com os posseiros. Títulos de propriedade emitidos por governos anteriores eram invalidados pelos seus sucessores.

A morosidade na emissão desses títulos e a falta de planejamento por parte do governo possibilitavam a expulsão de posseiros e de pequenos proprietários ('sitiantes') por pistoleiros a serviço dos latifundiários das imediações, como o que aconteceu, por exemplo, na região de Campo Mourão em 1948.

104 Por volta de 1950, o grupo Lupion detinha, entre outros negócios, 10 empresas de exportação, comércio e indústria no ramo madeireiro (KRETZEN, 1951, p. 143-145). A população 'elogiava' as diversas medidas controversas do governador pelo uso de uma nova forma verbal: lupionar = roubar, enganar. 
Além disso, a convergência descontrolada de pessoas em busca de terras nas colônias de ex-concessões que haviam retornado para o domínio do governo estadual dificultava uma divisão planejada das terras à disposição, provocando, consequentemente, reações violentas por parte dos posseiros desiludidos ${ }^{105}$.

Para além dos posseiros, das quadrilhas organizadas pelos latifundiários, dos grileiros, aventureiros, representantes do governo, políticos em busca de votos, pequenas empresas imobiliárias, do cultivo extensivo de milho para a engorda de porcos praticado pelos chamados 'safristas' e dos pequenos proprietários com direito de posse controverso, também as terras estaduais de fronteira se encontravam ameaçadas pela ação de criminosos ${ }^{106}$.

Em 1961, as disputas pela posse legal fora da região administrada pela CMNP diminuíram por meio da reordenação do Departamento de Terras e Colonização ${ }^{107}$, contudo continuaram a irromper de tempos em tempos em algumas regiões ${ }^{108}$.

As últimas grandes propriedades a se encontrarem em posse do estado situadas no Norte Novíssimo entre os rios Ivaí e Piquiri foram recolonizadas após 1955 - processo que perdurou, sob o impulso da cultura cafeeira, até o início da década de 1960, ao passo que a migração interna a partir do Rio Grande do Sul predominava ao sul do Piquiri.

A incerteza com relação às questões de posse em partes da área de colonização do estado conduziu a uma intensa exploração dessas propriedades, sobretudo em decorrência dos arrendamentos de curto prazo e da falta de medidas para a conservação da fertilidade do solo e para a diminuição da erosão na região do arenito Caiuá.

\section{DESENVOLVIMENTO DA PAISAGEM AGRÁRIA DO NORTE NOVO DO PARANÁ}

\section{a) Curso colonizatório e elementos povoadores}

Já na década de 1860 a cultura cafeeira paulistana, em sua expansão rumo ao oeste, havia ultrapassado o curso médio e o superior do rio Itararé e a fronteira da recém fundada província do Paraná.

Em um avanço territorial espontâneo, fazendeiros de Minas Gerais e de São Paulo cultivavam grandes plantações de café sobre o solo de sedimentos permocarboníferos do Segundo Planalto, constituído de numerosas intrusões diabásicas.

Com o surgimento da primeira colônia ${ }^{109}$, a frente pioneira avançou até o rio das Cinzas. A bissecção norte-sul do Planalto pelos afluentes do rio Paranapanema impediu o avanço da colonização para o oeste. Apenas no início do século XX é que se tomou posse da região nordeste do Terceiro Planalto paranaense.

A estação final da ferrovia sorocabana existente na época, Ourinhos (desde 1908), serviu como ponto de partida para a exploração dos solos vulcânicos de terra roxa. As plantações de café avançaram

105 Durante a revolta na região de Porecatu, ocorrida em 1950, membros do proibido Partido Comunista do Brasil atuaram pela primeira vez na zona rural, formando as assim denominadas Ligas Camponesas (WESTPHALEN et al., 1968, p. 36). Sucederam-se ações de transferência dos posseiros para as colônias Campo Mourão e Goio-Erê.

106 Especialmente a região de Faxinal de São Sebastião e a Serra da Pitanga foram alvo não somente das ações de bandos de caboclos insatisfeitos, mas também de fugitivos da lei (MARTINS, 1955, p. 100).

107 No ano de 1962 ainda havia pelo menos cerca de 1,5 milhões de hectares de terra em disputa fundiária em todo o Paraná.

108 Cf. no jornal Folha de Londrina, de 16 de junho de 1970 (p. 14), a declaração pública sobre direitos de propriedade dos legítimos proprietários dirigida ao estado do Paraná, no caso assim chamado 'Grilo dos Apertados': uma fazenda de 194.000 ha, situada na região do rio Paranavaí, havia sido dividida, sob a administração corrupta de Lupion, entre companheiros de partido, conhecidos senadores, cabos eleitorais etc.

Casos semelhantes a esse aparecem com frequência na imprensa diária paranaense, o que remonta a décadas, sendo que nenhuma das partes pleiteantes detém a efetiva posse da terra, visto que esta se encontra arrendada e subarrendada. Ademais, há também registros oficiais de casos de grileiros que, para obter crédito agrícola do Banco do Brasil, falsificaram títulos de propriedade.

109 Colônia Mineira, hoje Siqueira Campos (1862), Sto. Antônia da Platina (1866), Wenceslau Braz e Sao José da Boa Vista (1867) entre outras (FRANÇA, 1956, p. 188). 
com relativa lentidão até a região hoje denominada Cambará, que ganhou uma conexão privada com a estação de Ourinhos em 1925 (BERNARDES, 1952, p. 448) ${ }^{110}$.

Na década de 1920, as florestas tropicais das regiões de bacias hidrográficas em torno de Bandeirantes (1921) e Cornélio Procópio foram desmatadas, e em seu lugar foram cultivadas, segundo a tradição agrícola paulista, grandes plantações de café, antes mesmo da existência de uma malha ferroviária para o leste.

A necessidade de se estabelecer vias de acesso para as terras da Companhia de Terras Norte do Paraná localizadas a oeste do rio Tibagi levou à aquisição da companhia ferroviária existente pela CTNP. Partindo de Cambará (km 29), a construção da via férrea deu-se com uma rapidez incomum a partir de 1929, o que pode ser percebido pelos dados das estações de trem abaixo (MONBEIG, 1935, p. 16):

$\begin{array}{lrrr}\text { Ingá } & \mathrm{km} 57 & \text { abril } & 1930 \\ \text { Bandeirantes } & \mathrm{km} 82 & \text { julho } & 1930 \\ \text { C. Procópio } & \mathrm{km} 124 & \text { dezembro } & 1930 \\ \text { Jataí } & \mathrm{km} \mathrm{184} & \text { maio } & 1932\end{array}$

Contudo, a construção da ponte sobre o rio Tibagi fez com que a obra de construção da linha férrea sofresse um atraso de dois anos, sendo que o km 236 (que em 1934 se tornou Londrina, então elevada à categoria de cidade) somente foi alcançado em dezembro de 1935.

A colonização do Terceiro Planalto a oeste do rio Tibagi teve início por volta de 1920 com o avanço de colonos e caboclos rumo à região que hoje corresponde a Faxinal, os quais vinham do sudeste do estado, bem como do vale do Ribeira e da então decadente colônia Assungui.

A superação da cuesta triássica com altitude de até $1100 \mathrm{~m}$ recompensou os colonos com terras férteis e cobertas por florestas de araucárias situadas na orla sul da região do trapp basáltico, que foram espontaneamente ocupadas e agrimensadas pelo governo somente em 1925, sendo divididas em blocos irregulares de 50-200 ha (BERNARDES, 1953, p. 362).

No sistema de coivara, as plantações de milho, mandioca e abóbora cultivadas nas áreas desmatadas serviam para a engorda de porcos. Os animais eram conduzidos para Ponta Grossa, a estação de trem mais próxima localizada a uma distância de mais de $200 \mathrm{~km}$, onde anualmente eram vendidas até 30000 cabeças. ${ }^{111}$

Quase simultaneamente ocorreu um avanço controlado de colonização privada vindo do norte e passando pelo rio Paranapanema, que teve início com a ocupação nos anos 1922 e 1923 e com a fundação de Sertanópolis em 1925; esta, já em 1929, foi a primeira localidade a ser elevada ao status de município no Norte Novo (Mapa 15). Já a fundação privada da cidade de Primeiro de Maio demonstrou ser um equívoco, uma vez que os colonos foram afugentados pela malária e outras doenças tropicais decorrentes da baixa altitude da cidade ${ }^{112}$.

Na região pertencente à CTNP, os primeiros arroteamentos começaram em 1929 na cidade de Londrina, o ponto de partida da colonização, que deve seu nome a Londres, cidade sede da Paraná Plantations. A uma altitude de $610 \mathrm{~m}$ e cerca de $25 \mathrm{~km}$ a oeste do rio Tibagi foi construída uma casa para recepção dos novos colonos e um escritório.

A crise do café e a crise econômica mundial impediram a especulação de terras e a compra de terrenos agrimensados com, em média, 40 ha e pertencentes a pequenos e médios proprietários rurais por latifundiários. Como o estado do Paraná ainda não estava sujeito ao sistema de quotas

110 O impulso principal para o desenvolvimento do Norte Velho foi dado pelo cafeicultor Barbosa Ferraz Jr., de Ribeirão Preto, SP.

111 O desenvolvimento de Faxinal esteve intimamente ligado aos avanços colonizatórios da CTNP. Para lá foram vendidos, mais tarde, porcos jovens e porcos magros para engorda. A partir de 1935, Londrina assumiu, como estação de trem, cerca de um terço das exportações de suínos (MAACK, 1937, p. 238).

112 O fundador, Correia Pôrto de Abreu, regressou apenas em 1937 para o norte do Paraná, depois de 10 anos em São Paulo, e deu o impulso para a escolha de uma nova localização em terras altas, climaticamente mais favoráveis e situadas a uma distância maior dos vales de rios contaminados pela malária (KRETZEN, 1949; IBGE, 1959). 
de produção brasileiro devido a baixa produção de café, os terrenos agrimensados em forma de faixas (localizados em terras mais elevadas posteriormente arroteadas) também foram previstos para o cultivo do café.

Das seis grandes zonas de colonização, as zonas Tibagi e Pirapó, localizadas ao norte da bacia hidrográfica principal, foram as primeiras a serem exploradas com o avanço da frente pioneira do leste para o oeste, seguidas logo depois por Rio Bom, localizada ao sul (Mapa 14).

As primeiras propriedades foram adquiridas em 1930 na região de Londrina por colonos japoneses que, passando pelo Norte Velho, vieram do estado de São Paulo para a área de colonização da CTNP ${ }^{113}$. Terrenos localizados em torno da recém fundada cidade de Londrina foram adquiridos por um bom número de alemães e teuto-brasileiros que, em parte, já residiam há várias gerações no Brasil ${ }^{114}$.

$\mathrm{Na}$ mesma época, havia surgido ao norte de Londrina uma pequena colônia de alemães chamada Heimtal. Esses alemães haviam ganhado seu dinheiro para a compra de terras trabalhando na construção de estradas na região da ferrovia Sorocabana, contaminada pela malária e pela ancilostomose.

Quinze quilômetros a oeste de Londrina, colonos alemães vindos da cidade de Dantzig implantaram, em 1930, a colônia Nova Dantzig (hoje Cambé). Posteriormente, ambos os grupos não tiveram influência decisiva no desenvolvimento como um todo das respectivas colônias, sobretudo os trabalhadores de Dantzig, que não se ajustaram ao trabalho no campo.

Em face da situação econômica mundial por volta de 1930, da crise brasileira do café e da grande distância dos mercados, a venda de terras teve, a princípio, um início hesitante. Somaram-se a isso os temores com relação à infectação por malária e ao perigo das geadas e, em decorrência disso, da eventual pouca adequação das terras para a lavoura de café.

No início da colonização no norte do Paraná, a malária era endêmica em todas as áreas com altitude inferior a aproximadamente $450 \mathrm{~m}$, ocorrendo sobretudo entre os meses de outubro e março.

Os vales do grandes rios Ivaí e Piquiri ainda se encontravam totalmente despovoados, e os colonos também evitavam o vale do Tibagi. Dessa forma, a área de colonização da CTNP começava somente a partir de cerca de $20 \mathrm{~km}$ a oeste desse rio.

A ocorrência de casos de malária em Londrina estava diretamente ligada à construção da ferrovia, uma vez que muitos dos trabalhadores das equipes de arroteamento e seus familiares já estavam infectados e traziam a doença para o Norte do Paraná, a partir da área de construção da ferrovia da linha noroeste em São Paulo e do Mato Grosso do Sul ou da região costeira.

Uma vez que Jataí, localizada no vale do Tibagi, foi estação final da linha de trem entre 1932 e 1935, e os colonos, que geralmente chegavam ali no final da tarde, tinham de transpor o rio levados por balsas antes de continuarem a viagem para o oeste, o risco de contaminação tornou-se alto naquele lugar, que somente diminuiu com o término da construção da ponte e da conexão ferroviária sem interrupções ${ }^{115}$.

Antes da existência da conexão ferroviária para Londrina, os novos colonos eram transportados para a sua terra com família e bagagem às custas da CTNP, para o que se utilizavam as chamadas jardineiras - caminhões com carrocerias abertas providos de bancos -, que partiam da estação final da ferrovia, localizada no leste.

No ato de compra de terras, a qualidade do solo e o risco de geadas eram identificados por agrimensores experientes por meio da ocorrência de determinadas espécies de árvores ou de formações vegetativas. Na área pertencente à CTNP, até 1935 somente as encostas ao sul apresentavam ocorrência de geadas.

113 As terras da ex-fazenda Três Barras (45000 ha) situadas a leste do Tibagi foram vendidas quase simultaneamente pela empresa japonesa Soc. Colonizadora do Brasil Ltda. em forma de pequenas propriedades a colonos japoneses que trabalhavam ali sobretudo com o cultivo do algodão. A colônia japonesa Assaí acolheu até 1941 muitos dos japoneses vindos de São Paulo (de 1932 a 1941: 1384 famílias).

114 O primeiro terreno ('data') vendido na atual Londrina foi adquirido por A. Koch no dia 28 de novembro de 1930 (arquivo da CTNP). As 'datas' localizadas em torno de Londrina, medindo $13 \mathrm{~m}$ de frente por $40 \mathrm{~m}$ de comprimento, foram vendidas por um total que variava entre US\$13,00 e US\$ 15,00. Para evitar especulações concedia-se $50 \%$ de desconto àqueles que começassem a construção da casa dentro de um período de 6 meses (Little London in the forest, 1948, p. 5).

115 Maack (1937, p. 227-229). Em períodos relativamente secos, quando a falta de correnteza das águas favorecia o desenvolvimento do mosquito do gênero Anopheles em poças d'água, regiões localizadas até $600 \mathrm{~m}$ de altitude também eram assoladas pela malária. 
Aqui, as correntes descendentes de ar frio - morfologicamente determinadas e decorrentes da inversão térmica noturna - eram caracterizadas como limite de distribuição climática devido à ocorrência de araucárias nas encostas de vales profundamente entalhados, o que acontecia também abaixo da linha dos $500 \mathrm{~m}$ de altitude. ${ }^{116}$

Os primeiros terrenos foram concedidos nas proximidades dos assentamentos planejados, o que contribuiu para a diminuição do isolamento dos colonos. Vendas de terra posteriores foram efetuadas sistematicamente do centro para a periferia, sendo que as poucas terras cultiváveis maiores ficavam localizadas mais longe do centro a que correspondiam.

Depois da fundação de Rolândia em 1932 e do assentamento de imigrantes alemães, assim como da fundação da localidade de Arapongas em 1935, um fluxo maior de imigrantes se estabeleceu com o término da ferrovia que ia até Londrina (km 236: dez. de 1935).

Também contribuíram para isso as primeiras colheitas de café, que não tinham sido prejudicadas pela geada e que foram incomumente produtivas. Mas o verdadeiro boom do café somente começaria depois da Segunda Guerra Mundial, com o aumento do preço internacional devido ao repentino aumento do consumo.

Seguindo em sentido sul da bacia hidrográfica principal localizada entre Paranapanema e Ivaí, iniciou-se em 1938 o arroteamento para a construção do assentamento de Apucarana, que já em 1941 foi alcançada pela ferrovia, rapidamente construída até ali (Mapa 11) considerando-se que a altitude passava de $610 \mathrm{~m}$ em Londrina a $765 \mathrm{~m}$ em Rolândia, e chegava a $810 \mathrm{~m}$ em Apucarana.

A migração a partir do estado de São Paulo tornou-se cada vez intensa, sendo que aumentou a quantidade de descendentes de trabalhadores rurais italianos, que eram os principais arrendatários no Norte do Paraná ou formadores de cafezais. Eles adquiriam seus próprios terrenos.

A mistura bastante heterogênea dos elementos colonizadores se reflete já em suas nacionalidades (Tabela 3).

Imigrantes procedentes de mais de 20 países encontraram uma nova pátria no Norte do Paraná. Os compradores de terras registrados como 'brasileiros' na Tabela 3 eram oriundos de várias regiões do país, como São Paulo, Minas Gerais, sul do Paraná ou eram teuto-brasileiros vindos do Rio Grande do Sul.

Entre 1933 e 1941, metade dos compradores de terras da CTNP eram brasileiros e, em parte, também ítalo-brasileiros. O segundo maior grupo era formado por italianos, com pouco mais de $10 \%$, seguido pelos japoneses, alemães, espanhóis e portugueses.

Em decorrência do desenvolvimento político na Europa e no Leste Asiático e da participação dos países envolvidos na Segunda Guerra, a imigração de alemães, italianos e demais europeus, assim como de japoneses, parou totalmente perto do fim da década de 1930. Os compradores de terras dessas nacionalidades, registrados na tabela 3 nos três anos seguintes à guerra, são oriundos da migração interna brasileira.

As equipes de desmatamento eram formadas em sua maioria por baianos, os quais haviam se especializado largamente nesse tipo de trabalho. Junto a estes, lenhadores dos países bálticos também realizavam o desmatamento.

Trabalhadores itinerantes se juntavam a esse grupo vindos das áreas atingidas pela seca no Nordeste, encontrando trabalho durante a época de colheita do café no norte do Paraná. Espanhóis vindos de São Paulo, que como comerciantes de grãos se interessavam pela comercialização dos produtos da entressafra - a saber, milho e arroz - , ofereciam seus serviços como empreiteiros. ${ }^{117}$

Com relação à origem social dos imigrantes e às suas diferentes motivações para assentar-se na zona pioneira no Norte do Paraná, a colônia alemã de Rolândia representa um caso especial dentro das terras da CTNP.

116 A vantagem das áreas não sujeitas a geadas foi evidenciada em Londrina (altitude de $610 \mathrm{~m}$ ) em 1933, quando prejuízos decorrentes da geada afetaram as lavouras de café de São Paulo, sendo que em Londrina foi medida a temperatura mínima de + 0,1 ${ }^{\circ} \mathrm{C}$ (MAACK, 1937, p. 223).

117 O ‘empreiteiro’ é uma forma especial de arrendatário que se especializa na lavoura nova de café e, de acordo com o contrato, ganha como pagamento os produtos da entressafra do $1^{\circ}$ e do $4^{\circ}$ anos (cf. sobre isso p. 84ss. e Tabela 11, p. 85). 
茫

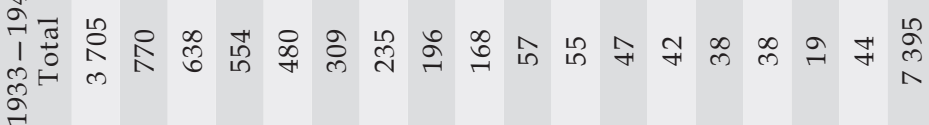

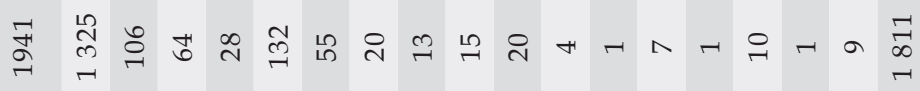

章辛

孚

色

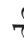

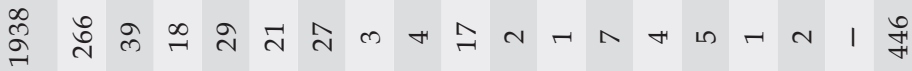

๙ิ

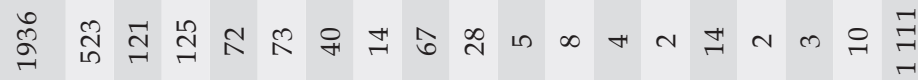

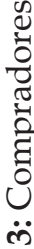

$\frac{\sqrt{-1}}{\frac{\pi}{0}}$

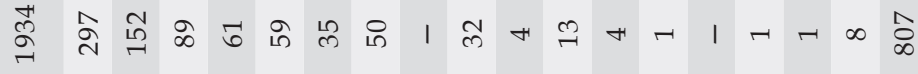

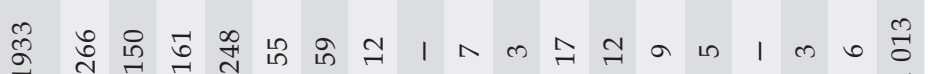

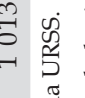

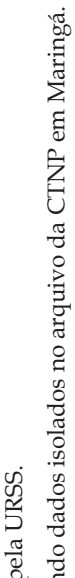

๙

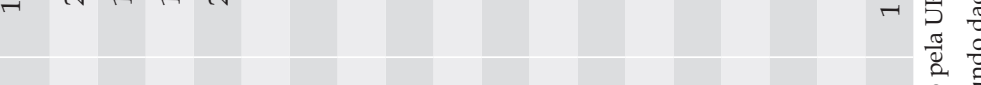

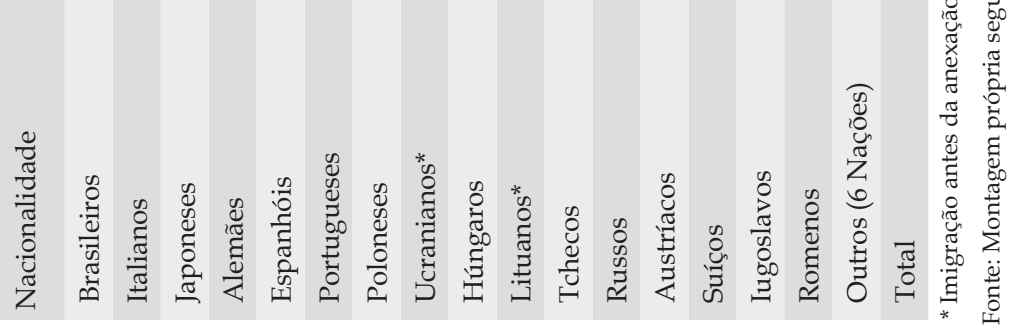




\section{b) Rolândia - Sucesso colonizatório de um assentamento de refugiados alemães ${ }^{118}$}

O surgimento e o desenvolvimento da colônia alemã Rolândia têm de ser analisados no contexto da imigração alemã e das tentativas de colonização no sul do Brasil e de seus países vizinhos no período entre guerras, levando-se em conta também o desenvolvimento político na Alemanha.

Em 1919/20, teve início no Rio Grande do Sul um movimento de emigração a partir das antigas áreas de colonização alemã para a colônia argentina de Misiones (Puerto Rico, San Alberto), bem como também para a colônia de Hohenau, localizada na margem paraguaia do rio Paraná.

Possibilidades de assentamento foram oferecidas aos novos imigrantes no nordeste de Santa Catarina pela Sociedade Colonizadora Hanseática [Hanseatische Kolonisationsgesellschaft], bem como às margens do rio Uruguai no Oeste do mesmo estado pela Companhia Colonizadora Chapecó-Peperí (diretor Faulhaber) (KOHLHEPP, 1966a).

A emigração espontânea de numerosos pequenos grupos bem como de um grande número de famílias alemãs que vieram para morar com parentes na América teve como consequência - durante o período da inflação - uma grande fragmentação e dispersão desses colonos também no sul do Brasil.

Negociações entre a Secretaria do Reich Alemão para Assuntos de Imigração [Reichsstelle für Auswanderungswesen], com sede em Berlim, e a Sociedade Paulista de Imigração e Colonização - uma associação de proprietários de plantações de café para a mediação da imigração de trabalhadores alemães para as fazendas de café de São Paulo - haviam falhado devido à revogação da travessia livre por parte do governo brasileiro.

Na década de 1920 foi realizada também no Brasil uma ação de ajuda caritativa bastante abrangente com o assentamento de colonos alemães da região da Volínea (Ucrânia), bem como de refugiados menonitas alemães-russos. Contudo, as precárias condições financeiras bem como a falta de planejamento e má escolha das terras levou a casos malsucedidos e à emigração de muitos colonos.

No ano de 1927, o ex-chanceler da Alemanha, Luther, fundou a Sociedade para Estudos Econômicos no Ultramar[Gesellschaft für wirtschaftliche Studien in Übersee], que era mantida por instituições financeiras, por companhias de navegação que lideravam o tráfego marítimo na América do Sul e por outras personalidades conhecidas.

O objetivo dessa sociedade, cuja presidência logo foi assumida pelo ex-ministro das Relações Internas de Alemanha E. Koch-Weser, era o de fomentar a colonização alemã planejada na América do Sul. ${ }^{119}$

$\mathrm{Na}$ Alemanha, a grande taxa de desemprego decorrente da crise econômica mundial acarretou a necessidade urgente da expansão dos projetos de colonização para o leste do país e da criação da possibilidade de assentamento no Ultramar. ${ }^{120}$ Por meio da iniciativa do Ministério das Relações Exteriores surgiu, em 1931, a Sociedade de Colonização no Exterior [Gesellschaft für Siedlung im Ausland (G. S. A.)]. ${ }^{121}$

No início de 1932, a Paraná Plantations Ltd. em Londres pediu à Sociedade para Estudos Econômicos no Ultramar para entrar em contato com alemães que desejassem imigrar. Nas negociações, uma área

118 Agradeço aos senhores cônsul honorário M. H. Bresslau, Dr. M. H. Maier, Dr. R. Loeb-Caldenhof, O. Nixdorf, G. Schlieper, Von Treuenfels, Kaphan e Rosenthal de Rolândia, entre outros moradores da colônia não citados, por numerosas informações pessoais gentilmente cedidas.

119 Viagens de estudos ao Brasil, Argentina, Chile e Uruguai realizadas pelo estudioso da área de pedologia, Prof. Vageler, e pelo especialista em colonização von Freeden (do serviço nacional de emigração [Reichsstelle $f$. Auswanderungswesen], Depto. América do Sul) contribuíram para pesquisas preparatórias (cf. sobre isso, entre outros, SCHAUFF, 1957a e 1959; KOCHWESER, 1957 e informações gentilmente cedidas por vários cidadãos de Rolândia).

120 O Serviço Nacional de Consultoria Migratória, com sede em Berlim, cujo diretor - o parlamentar Schauff, do Partido de Centro - e alguns outros colegas viriam a imigrar mais tarde para Rolândia, e a Companhia de Colonização Bauernland, sob a direção de F. W. Lübke (temporariamente também em Rolândia; após a Segunda Guerra Mundial, governador do estado de Schleswig-Holstein) e do ex-presidente alemão H. Lübke, trabalharam em conjunto sob o governo de Brüning na abertura de novos sítios para colonos depois da reforma agrária no leste da Alemanha após o fim da Segunda Guerra Mundial (cf. sobre isso: ROLAND, 1957, n. 5, p. 3).

121 A única colônia fundada pela G.S.A, entidade incorporada em 1933 pelo governo nazista, foi a de Terra Nova, formada por campos e floresta e localizada próxima de Castro, no leste do Paraná, o que ocorreu nesse mesmo ano (WAIBEL 1955a, p. 111ss.). Os colonos que vieram após 1935 para Terra Nova, assim como também, em parte, para Rolândia por intermédio da G. S. A. tinham de ser de origem "alemã, mais especificamente, ariana, conforme as Leis de Nuremberg". O preço da terra estipulado para 24,2 ha em Rolândia era de RM 1500 a 2000 [Reichsmark] e como capital de giro, RM 3000 (GESELLSCHAFT, 1937) 
maior de terras contíguas localizada a cerca de $25-30 \mathrm{~km}$ a oeste de Londrina havia sido reservada para os colonos, e um agricultor com experiência de trabalho em regiões tropicais foi imediatamente enviado como responsável pela colonização, conforme acordado. ${ }^{122}$

A área escolhida, denominada Roland, teve grandes dificuldades para se desenvolver, uma vez que, após a agrimensura e o preparo dos terrenos com a ajuda dos colonos vindos de Heimtal, os esperados colonos não chegaram devido à revolução em São Paulo em julho de 1932.

Somente a convocação de colonos teuto-brasileiros do sul do país é que possibilitou dar-se continuidade à colônia, cuja praça municipal, 'Rolândia', somente foi construída em 1934 com a abertura de uma conexão ferroviária para Londrina. Logo, vários imigrantes alemães se estabeleceram no leste da colônia (Schwabental).

Depois que o partido nazista tomou o poder na Alemanha, a composição dos elementos colonizatórios modificou-se rapidamente. Alemães perseguidos por motivos políticos, religiosos e étnicos procuraram refúgio em Rolândia.

Já em 1933 chegaram à colônia os ex-ministros Koch-Weser e Schlange-Schöningen, depois de terem analisado diferentes possibilidades de assentamento no Sul do Brasil em conjunto com outros líderes do movimento alemão pela reforma agrária e colonização, perseguidos pelo regime nazista. ${ }^{123}$

Além de opositores políticos do regime nazista, membros ativos de organizações juvenis confessionais imigraram para Rolândia, assim como também católicos do Partido de Centro [Zentrumspartei] e de associações dos trabalhadores. ${ }^{124}$

A restrição ao fluxo de saída de moeda estrangeira na Alemanha ${ }^{125}$ e as dificuldades da CTNP em transferir mil-réis brasileiros para a Inglaterra levaram ao desenvolvimento de um negócio de intercâmbios: a compra de material ferroviário da companhia ferroviária inglesa passou a ser efetuada - em vez de na Inglaterra - na Alemanha, onde o pagamento era feito com os bens dos imigrantes. Os valores foram transformados em crédito agrícola em Rolândia. Dessa forma, mais de 150 famílias, em sua maioria judias, puderam escapar das ameaças de perseguição na Alemanha depois da adoção da Leis de Nuremberg em 1935, assentando-se às margens do rio Pitangueiras em Rolândia. ${ }^{126}$ Um grupo ligado a E. Stinnes e ao conde Henckel von Donnersmarck teve participação importante no sucesso do intercâmbio ${ }^{127}$ e adquiriu, no decurso das transações, depois que a colonização havia transcorrido rapidamente para o oeste, grandes áreas de terras próximas a Apucarana, uma exceção na área administrada pela CTNP.

Entre as várias centenas de famílias alemãs que imigraram para Rolândia encontravam-se numerosos profissionais com titulação acadêmica. Ao lado de uma série de juristas que exerciam cargos no governo ou eram profissionais liberais, entre eles políticos e advogados renomados, havia médicos, economistas, engenheiros, professores universitários e não universitários, bancários, comerciantes e artesãos que vieram para Rolândia como refugiados por motivos políticos e religiosos, bem como em decorrência das leis raciais nacional-socialistas (MALER, 1957a, 1957b; ROLAND, 1957, n. 5; ISAY, 1960). Ao lado destes também haviam imigrado agricultores - de latifundiários a

122 O. Nixdorf foi incumbido dessa tarefa por ter acumulado experiência sobre os trópicos nos vários anos em que esteve em Sumatra, tendo escolhido assim a terra para os colonos. A área recebeu o nome de Roland, escolhido pelos fundadores (KochWeser, von Freeden, Nixdorf), todos de Bremen, o que foi aceito pela Companhia de Colonização inglesa (PRÜSER, 1957, p. 48 ss.).

123 Como, entre outras, a "Colônia de Associação Juvenil Heimat" [Jugendgemeinschaftssiedlung Heimat], fundada próxima a Timbó, Santa Catarina, pelo capelão berlinense Beil, onde cerca de 350 jovens católicos foram assentados no planalto em uma localização desfavorável, assim como a colônia Treze Tílias, fundada na região do Rio do Peixe, oeste de Santa Catarina, pelo ministro da agricultura austríaco Thaler com jovens colonos procedentes do Tirol do Sul.

124 A organização dessa emigração foi conduzida pelo já mencionado político de centro J. Schauff, que também propiciou a transferência de uma parte dos membros do malsucedido experimento de uma colônia de sociedade juvenil próxima a Timbó (ROLAND, 1957, n. 5, p. 4).

125 Até meados de 1934 era permitido a cada colono levar consigo um valor de até RM 10.000 em divisas (PRÜSER, 1957, p. 57).

126 Entre essas famílias estavam grupos de emigrantes procedentes de Duisburg e Düsseldorf.

127 O conde Henckel von Donnersmarck colocou à disposição sua influência, e o professor E. Stinnes, hoje residente nos EUA, seus contatos internacionais. Somente o bom trabalho em conjunto juntamente a representantes da CTNP, da Ferrostaal, de diversas instituições financeiras etc., sob a orientação de Koch-Weser em contato com organizações beneficentes judaicas e cristãs, é que possibilitou, sobretudo depois de novembro de 1938, a aquisição extremamente difícil de vistos e certificados de transferência. O presidente Getúlio Vargas permitiu, a pedido do Papa Pio XII, uma cota de vistos para colonos não arianos (ROLAND, 1957, n. 5, p. 5; SCHAUFF, 1957a). 
pequenos produtores - , bem como pessoas atuantes no sistema de colonização e de assentamento ${ }^{128}$, para os quais a experiência de colonização em uma área tropical foi proveitosa.

Apesar das extremas dificuldades de adaptação física e psicológica que esses imigrantes - em sua maioria vindos de centros urbanos - tinham de superar no arroteamento primitivo na frente pioneira, não demorou muito para que predominasse o espírito pioneiro e a ajuda mútua nas atividades agrícolas e de economia doméstica a que não estavam acostumados, e logo no início estabeleceu-se um sistema educacional e uma intensa vida cultural ${ }^{129}$. Em decorrência das compensações, alguns imigrantes adquiriram grandes propriedades em Rolândia, as quais chegavam a ter mais de 500 ha, mas ao chegarem tinham pouco capital de giro devido a rigorosas leis de câmbio, o que causou o atraso do desenvolvimento e, em alguns casos, uma crise e em parte venda de terra. O aumento do preço da terra, que em quatro anos chegou até a quadruplicar devido à grande procura, bem como os salários relativamente altos, também se mostraram bastante desfavoráveis (MAACK, 1937, p. 237).

Como, no entanto, alguns novos imigrantes já haviam transferido previamente grandes fortunas, colocou-se à disposição de colonos com poucos recursos a possibilidade de adquirir dinheiro em espécie por meio de serviços prestados nas propriedades maiores - sobretudo no oeste do distrito - o que foi especialmente vantajoso para os pequenos produtores no início da cultura de subsistência (AULICH, 1953, p. 215).

A chegada dos primeiros imigrantes a Rolândia em 1932/33 se deu em uma época em que a queima de grandes estoques de café excedentes em São Paulo fez com que o plantio desse produto não parecesse ser recomendável ${ }^{130}$. Depois dos arroteamentos iniciais e da construção de um rancho primitivo feito das metades dos troncos de palmeiras e coberto com telhas de madeira, ou mesmo de uma pequena casa de madeira feita de troncos, plantaram-se primeiramente alimentos básicos como milho, arroz, feijão e mandioca; mais tarde abriram-se pastos, criaram-se algumas cabeças de gado e praticou-se a engorda de porcos. Tentativas de se obter óleo de rícino e de tungue, bem como o cultivo de cana-de-açúcar e soja não foram comercialmente bem sucedidos ${ }^{131}$, pois em parte ainda faltava aos imigrantes alemães a experiência no cultivo desses produtos. Contudo, logo uma cooperativa agrícola assumiu tarefas organizacionais e consultivas. Com relação aos empreendimentos industriais em Rolândia, em 1937 já havia numerosas serrarias e fábricas de madeira compensada (MAACK, 1937, p. 238).

Contudo, a partir de 1963 - não menos por recomendação da CTNP - passou-se a cultivar café em um contingente cada vez maior. O plantio das lavouras de café foi deixado aos cuidados de empreiteiros de São Paulo com larga experiência e que - dependendo das condições financeiras do dono da terra - eram contratados com base em contratos de 4 a 6 anos de duração, e cujo pagamento consistia nas entressafras e na primeira colheita de café ${ }^{132}$. Eles costumavam se mudar para as casas pioneiras dos donos da terra, que nesse interim já tinham construído, em sua maioria, uma casa nova e maior.

Por meio do assentamento de alguns imigrantes suíços em Rolândia pretendeu-se diminuir as tentativas de instituições nacional-socialistas internacionais de exercer influência na região. A propaganda nacional-socialista teve como consequência a remigração de alguns dos primeiros colonos e acabou causando dissonância entre os refugiados, que vieram para cá por diferentes motivos. No entanto, com esforço conjunto os problemas foram logo superados.

Mas o cultivo do café mal havia sido introduzido em escala maior no final da década de 1930, quando a geada de 1942 ocasionou grandes perdas às plantações de café que se encontravam no seu estágio inicial. Para a continuidade do desenvolvimeto da colônia, foi de suma importância o fato de o governo brasileiro ter colocado crédito agrícola à disposição dos colonos, sem levar em conta a nacionalidade destes apesar do estado de guerra com a Alemanha.

A área de reserva prevista para colonos alemães em Rolândia foi vendida a outros colonos durante a guerra, uma vez que a imigração tinha ficado totalmente interrompida em decorrência

128 Entre outros, alunos de Sering e Aereboe.

129 Maier (1957a, p. 26-27). A assim chamada associação colonial assumiu a responsabilidade de cuidar das instituições culturais e a autoadminitração da colônia.

130 Koch-Weser (1957, p. 56-57). Contudo, conforme decreto federal de 19/12/1932, o cultivo de pés de café era permitido nas terras pertencentes à CTNP.

131 Dessa forma, a construção de uma fábrica de açúcar não foi efetuada como havia sido prometido pelo governo federal (relato oral do Sr. G. Schlieper, Rolândia).

132 Cf. sobre isso em geral p. 84/86 e Tabela 11, p. 85. - cap. IV - Expansão do cultivo de café. 
das ações de guerra. Com a exceção de certas restrições de viagem e a proibição do uso da língua, bem como da venda de terras, os colonos alemães de Rolândia, da mesma forma que seus vizinhos italianos e japoneses, não foram impedidos por quaisquer medidas econômicas coercivas por parte do governo brasileiro ${ }^{133}$.

Com o início da exportação livre de café em fins da década de 1940 e o consequente boom do café, iniciou-se a fase principal de desenvolvimento econômico em Rolândia, cuja localização em uma região de solos ricos de terra-roxa e altitude apropriada deram condições ideais para o cultivo do café, um desenvolvimento que não podia ser previsto de início.

\section{c) Tendências de exploração e fundações de colônias}

O assentamento de imigrantes e seus descendentes em áreas de colonização fechada teve seu fim com os esforços de nacionalização no Brasil. Depois de 1938, o governo brasileiro empenhouse em assentar grupos estrangeiros da maneira mais espalhada possível entre colonos nativos. Até aquele momento, a região em torno de Nova Dantzig (Cambé) era caracterizada sobretudo pela colonização italiana, Rolândia pela alemã, Arapongas e Mandaguari, por sua vez, pela espanhola e sua descendência.

Com tal movimento populacional de luso-brasileiros e também de brasileiros descendentes de italianos, japoneses e espanhóis que avançava, sobretudo, de São Paulo em direção ao oeste, deparou-se um contingente imigratório de poloneses, bielorrussos, bem como de teuto-brasileiros vindos das antigas regiões de colonização no sul do Paraná, em parte também da área de colonização estatal malsucedida em torno de Faxinal. Apucarana desenvolveu-se sobretudo como estação ferroviária terminal de 1941 a 1948 , tornando-se o grande melting-pot dos diferentes elementos populacionais ${ }^{134}$.

Outro avanço populacional vindo do sul que, no entanto, não pôde estabelecer nenhum contato com a real zona de café até a década de 1950 deu-se primeiramente de modo espontâneo entre Piquri e Ivaí e, a partir de 1939, no âmbito da colonização estatal oficial, na qual por volta de 1940 a ramificação mais ao norte correspondia à região em torno de Campo Mourão (Mapa 11).

Nesse lugar já se encontravam estabelecidas algumas famílias de caboclos desde o início do século XX como os postos avançados mais distantes na pequena ilha de 'campo cerrado', na despovoada área de transição da mata subtropical para a Mata de Araucária. Campo Mourão era a entreestação na criação de gado do Mato Grosso do Sul, passando por Porto Camargo, às margens do rio Paraná, em direção aos ‘campos limpos' de Guarapuava. Em 1934, viviam aproximadamente 250 famílias em Campo Mourão. A região a oeste até o rio Piquiri ainda estava totalmente despovoada ${ }^{135}$.

Nas vastas áreas de floresta às margens do Piquiri, que se estendiam até a divisora de águas em direção ao Ivaí, em 1936 havia se configurado a possibilidade de uma colonização com imigrantes suíços desempregados, para os quais foram reservadas terras oficiais de no máximo 500.000 ha pelo período de um ano. O projeto, que previa investir os pagamentos de benefícios de desemprego por parte do governo suíço na administração da colônia e que oferecia a oportunidade de saldar o preço total de compra (3,15 francos suíços por hectare) por meio da construção de mais de $225 \mathrm{~km}$ de estradas (MOESCHLIN, 1936, p. 22 ss.), ${ }^{136}$ fracassou, uma vez que uma quota anual específica de imigração da Suíça não podia ser garantida.

A partir do ano de 1939, no âmbito da colonização estatal, ocorreu nessa região uma colonização de uma área de 130.000 ha nas colônias Mourão, Goio-Bang, Cantú e Piquiri. Na região do Piquiri, houve tanto a participação de 'caboclos' como também de descendentes de poloneses e de ucranianos, que trabalhavam como 'safristas' no movimento de expansão espontâneo baseado na criação de porcos. Por sua vez, a região em torno de Campo Mourão recebeu, depois da abertura de uma picada primitiva em 1945 em direção à planejada Maringá, o afluxo de colonos vindos do Rio Grande do Sul e de Santa Catarina, primeiramente sobretudo de origem italiana, mas mais tarde também de origem alemã. Vindo

133 Prüser (1957, p. 60-61) e informações pessoais obtidas em Rolândia.

134 Pelos nomes dos primeiros colonos de Apucarana é possível perceber as migrações internas diferenciadas etnicamente de diferentes origens: entre outros, Vieira dos Santos, Almeida, Oliveira Rosa; Massaretto, Bonetto, Carlini; Gomez, Gonzales; Kinoshito; Kaniowski; Glück, Schmidt etc. (EL-KHATIB, 1969, v. 4, p. 24).

135 Cf. sobre isso o relatório da expedição de Maack de 1934 (MAACK, 1936 e 1937, p. 212).

136 Moeschlin (1936, p. 22 ss.) - Pensava-se aqui em uma conexão rodoviária com um porto no rio Paraná, planejado para ser construído, entre Porto Mendes e Foz do Iguaçu. 
do norte em direção ao sul avançavam paulistanos, mineiros e baianos, penetrando até os limites das áreas com condições climáticas para o cultivo do café $e^{137}$.

A exploração do norte do Paraná foi significativamente determinada pelo afluxo de compradores de terras na área da CTNP, onde os ricos solos de 'terra-roxa', o clima tropical ameno e a segurança por meio da emissão dos títulos de propriedade logo ficaram conhecidos em todo o Brasil. O problema da localização do norte do Paraná, longe dos portos de exportação e dos centros populacionais da região costeira foi amenizado após conclusão de uma conexão ferroviária e da expansão da malha rodoviária.

O fácil acesso às propriedades tinha um valor especial, o que se deve à bem planejada e executada construção de ruas e estradas por parte da CTNP. As ruas dentro da área de colonização foram construídas com uma largura de $5 \mathrm{~m}$, sendo que mais $5 \mathrm{~m}$ foram desmatados para ambos os lados da rua para facilitar o secamento das ruas depois de chuvas. Após 4 anos, a CTNP já havia construído mais de $400 \mathrm{~km}$ de ruas, cuja constante manutenção e melhoria era realizada com incomum cuidado. Em 1950, havia uma malha rodoviária de $3.000 \mathrm{~km}$ de extensão! (Mapa 12). Uma vez que as conexões de ruas e estradas foram todas construídas em condições de superfície levemente ondulada sobre as cristas que se estendiam por longas distâncias, e as ruas secundárias terminavam na parte baixa do declive, os custos com obras de engenharia nas principais vias de acesso foram bastante baixos. A expansão da malha rodoviária e da venda de terra se deu no mesmo ritmo, contudo sempre crescente.

Como desde 1940 já havia se dado um forte aumento na venda de terras, o preço da venda de sítios aumentou significativamente a partir de 1945, devido à expansão da produção de café atrelada ao aumento dos preços do mercado mundial. Somente no período entre 1945 e 1950, a CTNP vendeu 482.000 ha de terra, ou seja, quase dois quintos do total da área original da concessão.

Contudo, mais impressionante do que isso foi o aumento do número de propriedades vendidas nos pequenos centros urbanos e 'patrimônios'.

Tabela 4: Venda de Terras e Construção de Estradas na área da CTNP

\begin{tabular}{|c|c|c|c|c|}
\hline & $\begin{array}{c}\text { Venda de terras } \\
\text { em ha }\end{array}$ & $\begin{array}{c}\text { Proporção de } \\
\text { concessão original* }^{*} \\
\text { em \% }\end{array}$ & $\begin{array}{c}\text { Venda de propriedades } \\
\text { urbanas }\end{array}$ & Estradas em km \\
\hline 1930-1934 & 57.000 & 4,6 & 1.088 & 421 \\
\hline 1935-1939 & 82.000 & 6,5 & 1.705 & 480 \\
\hline 1940-1944 & 290.000 & 23,3 & 3.329 & 592 \\
\hline $1945-1950$ & 482.000 & 38,7 & 12.071 & 1.507 \\
\hline $1930-1950$ & 911.000 & 73,1 & 18.193 & 3.000 \\
\hline
\end{tabular}

* $12.463 \mathrm{~km}^{2}$

Fonte: Dados da CTNP.

Ao contrário do frontier paulistano, a construção das cidades no Norte do Paraná foi em grande parte planejada. Além disso, os centros urbanos construídos de acordo com conceitos de planejamento urbano modernos e os pequenos assentamentos urbanos dentro da área da Companhia de Terras Norte do Paraná diferiam dos assentamentos espontâneos ou em parte mal planejados encontrados no restante do norte do Paraná.

As localizações dos centros urbanos foram estabelecidas, sem exceção, por razões medicinais e de tráfego pelo departamento de agrimensão da Companhia de Colonização nas partes mais altas do relevo. Na fundação da primeira colônia, Londrina, a planta foi esquematicamente criada em sistema ortogonal (Mapa 13), sendo que a praça ocupou a parte mais alta da área a ser construída. Contudo, esse padrão rígido, com suas ruas cruzando-se perpendicularmente, revelou-se desfavorável devido ao

137 Martins (1955, p. 108); C. Bernardes (1950, p. 579/80; 1953, p. 350ss.), bem como Bernardes (1952, p. 447). Cf. sobre isso também os Mapas 10 e 11. 
desnível apresentado pela cidade. Com o aumento da população urbana, a área de 325 ha reservada para o estabelecimento da colônia também logo se mostrou insuficiente.

Com base nessa experiência, o segundo maior centro urbano, Maringá, localizado a aproximadamente $125 \mathrm{~km}$ a oeste de Londrina, foi estabelecido com dimensões muito mais generosas em uma área mais que quatro vezes maior (Mapa 14 e Tabela 5).

A fundação de Maringá se iniciou com a construção de uma grande área para pouso de aviões. A cidade foi planejada para comportar, futuramente, uma população de 100.000 habitantes, e apresentava em uma boa adaptação às condições morfológicas uma planta regular mas modificada pela aplicação de padrões radiais e semicirculares. Largas avenidas com até $48 \mathrm{~m}$ de largura (mas geralmente com 30 $\mathrm{m}$ ), com duas faixas separadas por canteiros, suavizavam a ampla e vasta área, que desde o princípio foi dividida em sete zonas funcionalmente diferenciadas e que era atravessada, em trajeto semicircular, pela já planejada ferrovia. Em ambos os lados da ferrovia criou-se um amplo corredor para oficinas de reparação, armazéns e pátios de estocagem, empresas comerciais e industriais. A estação de trem localizava-se no centro, muito próxima ao centro comercial da cidade. Os bairros, classificados com rigidez hierárquica, foram estruturados em três categorias (padrão alto, médio e baixo), e se interligavam a sul, sudoeste, sudeste e norte.

A rua principal corria em geral perpendicularmente à linha férrea, em direção à estação. Esse padrão não foi aplicado apenas em Maringá, mas já anteriormente no planejamento das localidades de Arapongas, Apucarana (estação fora da cidade), Pirapó, Jandaia, Mandaguari, Marialva e Sarandi. Por razões topográficas, esse padrão foi modificado em Londrina, Cambé e Rolândia. As plantas de pequenos assentamentos também foram adaptadas às condições topográficas.

Com base nas experiências obtidas em Londrina, as plantas regulares das cidades que foram fundadas mais tarde não foram mais divididas em forma de quadrados, mas em retângulos. Desse modo, deveria evitar-se a divisão mais complicada dos quadrados da planta em locais de construção retangulares, e, associado a isso, a consequente desvantagem higiênica dos lotes centrais em decorrência da instalação de fossas nos fundos das propriedades adjacentes.

Os pequenos centros, que primeiramente tinham apenas uma função de abastecimento e de mercado para as "chácaras' e "sítios" localizados em suas proximidades, cresceram rapidamente (MAACK, 1937, p. 234):
Londrina
1930-1936:
1.200 casas
Rolândia
1934-1936:
500 casas
Arapongas
1935-1936:
100 casas

Por outro lado, uma área de assentamento japonês dispersa, localizada ao sul de Nova Dantzig (Nova Tokio, atual Caramuru), não possuía sequer um centro próprio.

O grande número de pequenos proprietários dentro da área da CTNP contribuiu significativamente para o crescimento das colônias que haviam sido fundadas, cuja importância central em nível comercial e cultural crescia continuamente.

Os 'patrimônios' fundados pela CTNP (p. 52 e Mapa 14) desenvolveram rapidamente uma vida empresarial ativa, e ao rápido aumento da população seguiu-se logo também a reorganização da estrutura de gestão e da elevação à categoria de 'vila', ou seja, a sede distrital ou até mesmo municipal.

O Mapa $14^{138}$ analisa a ascensão das colônias fundadas pela CTNP, as quais atualmente se tornaram quase todas municípios e que se estendem ao longo da linha divisora de águas em uma impressionante sequência.

Além disso, foi fundado também um número significativo de 'patrimônios' privados nas propriedades da CTNP. Estes eram criados em grande parte longe dos principais eixos com a aprovação da Companhia, cujas terras continuaram a ser valorizadas pela fundação de novas colônias. Assim, um comprador de terras interessado em negociar demarcava em sua terra um assim chamado "patrimônio"139,

138 O processo de desenvolvimento da colonização será descrito em maiores detalhes posteriormente, por meio do Mapa 14 em conjunto com a Figura 3.

139 Em termos da gênese das colônias, o 'patrimônio' era uma forma ampliada da capella, o local de encontro religioso e ponto central das fazendas do séc. XVIII. O patrimônio também era, enquanto presente para a Igreja Católica, dedicado a um santo. As dimensões do patrimônio demonstravam a posição econômica do fazendeiro. A quantia recebida pela venda das 
centro de uma futura colônia, e vendia os lotes 'urbanos' (500-800 $\left.\mathrm{m}^{2}\right)$ a interessados. Os gastos com agrimensão e planejamento eram em muito superados pelas receitas provenientes da venda dos lotes e pela valorização da sua própria terra, adjacente a nova colônia.

Particularmente importante foi o estabelecimento de instituições cruciais como escola, farmácia, médico, dentista, notário, loja de artigos têxteis, bem como armazém, hotel, pousada, bares, oficina, posto de gasolina, mas também de máquinas de beneficiamento, como as de café e de arroz, bem como uma serraria.

Alguns desses patrimônios privados experimentaram, em decorrência da economia cafeeira e em parte também por razões políticas, uma rápida ascensão ao status de sede do distrito e, em lugares um pouco mais isolados, a sede do município, principalmente na vertente em direção ao Ivaí (Mapa 14).

Devido a um número grande demais de localidades fundadas, as zonas de influência se sobrepuseram de modo desfavorável, inibindo o desenvolvimento. Embora as localidades fundadas pela CTNP tivessem um papel dominante no Norte Novo, em alguns casos elas foram suplantadas por localidades fundadas por iniciativa privada. Assim, por exemplo, a localidade de Maristella, fundada pela CTNP às margens da estrada de Maringá para o Noroeste, que até hoje permanece apenas como sede distrital (Mapa 14 e Tabela 5, número 27), enquanto a vizinha imediata, Alto Paraná, ascendeu à sede do município. O mesmo vale para Guadiana (número 20), que foi superada em muito em importância pela localidade de Mandaguaçu.

Em áreas com um avanço da população pioneira ligado à construção da ferrovia, a estação ferroviária terminal exercia uma particular influência sobre o desenvolvimento regional. Com o fim da linha férrea, o desenvolvimento das vias de acesso terminava e a colônia que se desenvolvia na estação terminal e as células de arroteamento que dela partiam eram portas de entrada para as áreas de florestais tropicais ainda não povoadas em torno delas. No Brasil, esses lugares são chamados de 'boca de sertão'.

No Estado de São Paulo, Ribeirão Preto, Barretos, Rio Preto, Bauru, Ourinhos e, mais recentemente, Marília foram estações terminais desse tipo ${ }^{140}$. Atrasos na continuação da construção da linha férrea favoreciam o povoamento da cidade. A construção da ferrovia era também frequentemente interrompida propositalmente, dando à planejada colônia uma boa posição inicial com a absorção do fluxo de pessoas que para ali afluíam.

Ao contrário do oeste de São Paulo, onde a distância de $20 \mathrm{~km}$ entre as estações ferroviárias comprovou ser geralmente muito pequena, tendo em vista a predominância do latifúndio, e as estações demonstraram não ser viáveis enquanto células de colônias, no Norte do Paraná, a distância de 15 km foi totalmente aceitável diante de um povoamento muito mais denso.

propriedades com patrimônios era aplicada na construção da igreja, no pagamento do religioso e para o uso das instalações religiosas. Além do puro ato de piedade, o fazendeiro tinha em vista a expansão do patrimônio, a venda de suas próprias terras adjacentes e a valorização geral de suas posses, um procedimento que estava ligado frequentemente aos interesses do padre.

Desde o início do séc. XX predominava, contudo, o patrimônio secular, o qual o proprietário das terras planejava em planta ortogonal, agrimensava e cujos locais de construção eram vendidos ou arrendados. O fazendeiro se tornava o povoador, ou seja, o fundador da colônia. Os patrimônios não levavam mais nomes de santos, mas frequentemente o nome do fundador. Propriedades precisavam ser edificadas dentro de um prazo (de até um ano) e construções especiais demarcavam as frontes das ruas em torno da praça (DEFFONTAINES, 1938, p. 390 ss. e MONBEIG, 1952, p. 310 ss.). Em áreas com latifúndios foram estabelecidos, em parte, patrimônios para se ter à disposição, em uma localização imediata, um bom número de trabalhadores para a época da colheita. Como chamariz para o assentamento, concedeu-se pequenas chácaras de graça para os imigrantes para o cultivo de alimentos básicos (LEHMANN, 1958, S. 90/91).

140 No Estado de São Paulo, Marília é um exemplo impressionante de cidades ‘boca de sertão': Marília foi fundada em 1925 às margens da linha férrea Alta Paulista e já contava, em meados dos anos 1930, com uma população de 20.000 habitantes (sobre isso, entre outros, DEFFONTAINES, 1938, p. 388; e em geral MONBEIG, 1935 e 1952; bem como GUTERSOHN, 1940) 
Tabela 5: Fundações de colônias da Companhia de Terras ou Melhoramentos Norte do Paraná (conforme áreas reservadas acima de 50 ha)

1. Cianorte

2. Maringá

3. Umuarama

4. Londrina

5. Nova Esperança

6. Mandaguari

7. Terra Boa

8. Arapongas

9. Apucarana

10. Rolândia

11. Jandaia do Sul

12. Marialva

13. Cambé

14. Jussara

15. São João do Caiuá

16. Paiçandu

17. Florida

18. Cruzeiro do Sul

19. Indianópolis

20. Guadiana

21. Inajá

22. São Tomé

23. Sabaudia

24. Sarandi

25. Perobal

26. Dr. Camargo

27. Maristella

28. Santo Antonio do Caiuá

29. Água Boa

\begin{tabular}{|c|c|}
\hline & Fundaçãc \\
\hline 1865 ha & 1953 \\
\hline 1463 ha & 1947 \\
\hline 802 ha & 1955 \\
\hline 325 ha & 1930 \\
\hline 272 ha & 1948 \\
\hline 252 ha & 1937 \\
\hline 235 ha & $1955^{*}$ \\
\hline 228 ha & 1935 \\
\hline 211 ha & 1938 \\
\hline 200 ha & 1932 \\
\hline 184 ha & 1951 \\
\hline 148 ha & 1940 \\
\hline 146 ha & 1930 \\
\hline 136 ha & $1955^{*}$ \\
\hline 130 ha & 1951 \\
\hline 99 ha & $1960^{*}$ \\
\hline 80 ha & 1955 \\
\hline 74 ha & 1952 \\
\hline 74 ha & $1967^{*}$ \\
\hline 71 ha & D \\
\hline 69 ha & 1955 \\
\hline 63 ha & $1960^{*}$ \\
\hline 59 ha & 1945 \\
\hline 58 ha & $\mathrm{D}$ \\
\hline 58 ha & $\mathrm{D}$ \\
\hline 57 ha & $1964^{*}$ \\
\hline 54 ha & D \\
\hline 52 ha & 1961 \\
\hline 50 ha & $\mathrm{D}$ \\
\hline
\end{tabular}

* A data indicada designa aqui a elevação à sede do município

D atualmente: sede distrital

(Fonte: arquivo da CMNP) situação em 19.01.1970 (Mapa 14).

No norte do Paraná, Apucarana tirou proveito de sua posição enquanto 'boca do sertão' durante quase 10 anos. A linha férrea tinha chegado à cidade em 1941 e continuou a ser construída em direção a Maringá apenas no início dos anos 1950, onde chegou apenas em 1954. Esse atraso foi motivado pela aquisição da companhia ferroviária inglesa pelo Estado, cuja permanente escassez de recursos financeiros não permitiu dar continuidade à planejada linha férrea, que passaria originalmente por Guaíra, chegando até Asunción.

Enquanto Apucarana vivenciou um avanço significativo como estação ferroviária terminal até fins da década de $1940^{141}$, Maringá havia atingido em 1954 - embora existisse há apenas 7 anos - um estágio mais elevado de desenvolvimento devido ao tráfego de caminhões e ônibus em forte expansão.

O desenvolvimento das áreas de floresta tropical situadas mais ao oeste, para além do rio Ivaí, deu-se com a rápida construção de estradas na era do automóvel. Até a data da publicação da primeira edição deste livro a conexão férrea entre Maringá e o centro urbano mais próximo, Cianorte, ainda não havia sido concluída. A partir de meados dos anos 1950, a construção da ferrovia não exerceu mais influência alguma sobre o desenvolvimento regional. A função das localidades 'boca de sertão' passou a ser exercida pelas colônias situadas nos pontos finais das ruas pavimentadas, nas quais o tráfego de

141 Waibel (1948, p. 628) descreve a grande quantidade de lojas de todo tipo 'repletas de produtos'. Numerosos hotéis, pousadas, mas também bares, salões de beleza, grandes depósitos de madeira definiam a atmosfera da estação ferroviária terminal de uma importante ferrovia. 
caminhões e veículos de passageiros se intensificava depois de fortes chuvas, pelo fato de as pistas de terra roxa ou de areia ficarem intransitáveis até que estivessem secas.

O progresso econômico do norte do Paraná, sobretudo o boom do café que se delineava lentamente, levou a um rápido aumento do preço das terras. Se em Londrina o $\mathrm{m}^{2}$ do terreno era vendido a três centavos em 1931/32, em 1948 teve-se de pagar por ele US\$ 50. Desde sua fundação em maio de 1947, o preço de terrenos em Maringá centuplicou no período de um ano! Um sítio nos arredores de Londrina, que podia ser adquirido por 200 dólares em 1932, era vendido em 1948 com 9.000 pés de café já produzindo por US\$ $15.000 .{ }^{142}$

Com os primeiros lucros financeiros significativos em decorrência de boas safras de café, os pequenos proprietários do Norte Novo em torno de Londrina podiam adquirir para os seus filhos novas terras na região de Maringá e, mais tarde, também além do rio Ivaí.

A recém fundada cidade de Maringá oferece um exemplo do rápido estabelecimento do processo de desenvolvimento na região de terra-roxa no Norte do Paraná. Após 3 anos de existência, já haviam sido construídas, em 1950, mais de 1.200 casas, 320 lojas, 75 fábricas e pequenas indústrias, 8 igrejas, 3 hospitais, 4 filiais bancárias, 4 clubes esportivos e duas escolas com 1.200 alunos. O campo de pouso, com uma pista de 1.600 m, contava com várias conexões semanais para São Paulo e demais colônias urbanas no Norte Novo do Paraná.

O desenvolvimento e colonização da região em torno de Maringá trouxe um avanço significativo da colonização rumo ao oeste em direção ao rio Paraná, e inaugurou, com o início do boom do café, o avanço das frentes de arroteamento na região do arenito Caiuá. As condições ecológicas em modificação e a passagem para uma nova fase colonizatória, com um alvo econômico com base na produção exclusiva de café, ou seja, critérios naturais e espaço-temporais, econômicos e de geografia social caracterizam a passagem para o assim chamado Norte Novíssimo, as zonas pioneiras dos anos 1950.

Antes disso, contudo, deve-se elucidar o desenvolvimento populacional que ocorreu até 1950 e procurar estabelecer-se a situação da colonização por volta de 1950.

\section{d) Desenvolvimento populacional e situação da colonização por volta de 1950}

Nas duas décadas entre 1930 e 1950 houve uma imigração de mais de meio milhão de pessoas para a região ao norte do rio Piquiri e a oeste do Tibagi. No ano de 1950, 60\% da população dessa região vivia na área de colonização da CTNP.

Se em 1932/33 a população total dessa parte do terceiro planalto era apenas de cerca de 27.000 habitantes (MAACK, 1937, p. 211) em uma área de $75.000 \mathrm{~km}^{2}$, esse número aumentou, até 1940, para 117.000 habitantes (Tabela 6, p.303, Anexo). Conforme demonstra o Mapa 11 referente ao desenvolvimento do norte do Paraná, a colonização se concentrava em uma faixa de até $25 \mathrm{~km}$ de largura a oeste do rio Tibagi, assim como em um corredor de 10 a $30 \mathrm{~km}$ de largura ao longo da ferrovia que se expandia no sentido oeste-sudoeste até as proximidades de Apucarana. Ao mesmo tempo, as regiões periféricas do planalto entre Tibagi e Ivaí estavam ocupadas por uma população pouco estabelecida.

O censo populacional de 1940 desmonstrou haver uma população de 23.000 habitantes $^{143}$ para toda a região ainda não desenvolvida do atual Norte Novíssimo, que corresponde à região a oeste do rio Pirapó e a sul do Paranapanema até o Piquiri, no sul, e o Paraná, no oeste, a qual se estabeleceu em algumas passagens dos rios Paraná e Paranapanema, assim como em torno de Campo Mourão e na região da antiga Fazenda Brasileira ${ }^{144}$, ou espalhada nas florestas como uma população de lenhadores ou colhedores de mate.

142 Little London [Pequena Londres], 1948, p. 17.

143 A distribuição regional da população em 1940 - ao norte do Ivaí existiam apenas os municípios de Sertanópolis e Londrina e ao sul, apenas Guarapuava (Mapa 15) - foi calculada pelo autor segundo informações fornecidas na CIBPU em 1958, com base em áreas regionais como se encontram atualmente.

144 A enorme fazenda que se encontrava na região onde atualmente é a cidade de Paranavaí, em cujas terras havia sido plantado café já na década de 1920, passou a pertencer, em 1930, ao Estado do Paraná. Desde 1915/16 havia sido estabelecido um caminho de gado que saía de Porto São José às margens do rio Paraná (o ponto de conexão para o Mato Grosso) em direção à sede da Fazenda Brasileira (atual Paranavaí) e avançava para Campo Mourão e Guarapuava. Depois de 1930, plantações e instalações entraram em declínio, e somente em 1944 começou a definitiva colonização urbana da Colônia Paranavaí, com a agrimensão de 400 lotes entre 100 e 130 ha. 
Nos 10 anos entre 1940 e 1950, a população da área estudada quintuplicou, o que se deveu principalmente ao crescimento populacional no Norte Novo de Londrina entre os rios Tibagi e Pirapó ${ }^{145}$. Lá o número de habitantes subiu de 69.000 (1940) para 327.000 (1950). Enquanto o Norte Novo se encontrava em fase de estabelecimento nos arredores de Apucarana e na primeira fase de ocupação nos arredores de Maringá, o Norte Novíssimo, uma área de quase $36.000 \mathrm{~km}^{2}$, somente foi alcançado pelo avanço da população no início da década seguinte (1960). De 1940 a 1950, o total do crescimento populacional foi de apenas 50.000 habitantes.

Ao aumento da população seguiu-se a divisão administrativa entre os rios Tibagi e Pirapó, afluentes do Paranapanema. Do município de Sertanópolis foram separadas Ibiporã, Bela Vista do Paraíso, Jaguapitã e Porecatu; de Londrina, os novos municípios de Cambé, Rolândia, Arapongas, Apucarana e Mandaguari. Este último compreendia, por volta de 1950, o Norte Novo de Maringá e a área total entre os rios Paranapanema, Paraná e Ivaí (Mapa 15, 1940, 1950).

A maior colônia do Norte do Paraná, Londrina, cresceu de 10.500 (1940) para quase 34.000 habitantes (1950) e obteve, como único município, apesar do grande território, uma maior imigração urbana do que rural.

A densidade populacional no nordeste da área estudada ficou entre 15 (Jaguapitã) e $87 \mathrm{hab} / \mathrm{km}^{2}$ (Cambé). A média da densidade populacional rural no Norte Novo de Londrina atingia cerca de $25 \mathrm{hab} / \mathrm{km}^{2}$, em torno de Maringá $12 \mathrm{hab} / \mathrm{km}^{2}$ e na região de Apucarana, $10 \mathrm{hab} / \mathrm{km}^{2}$ (Tabela 7, p. 304, Anexo). Ao sul do Ivaí, os números da densidade populacional de pouco mais de $1 \mathrm{hab} / \mathrm{km}^{2}$ indicam o estado em que se encontrava a colonização por volta de 1950.

A situação geral da distribuição populacional em 1950 é elucidada no Mapa 16. Em São Paulo, a 'fronteira' havia chegado ao rio Paraná na segunda metade da década de 1940. A expansão da cafeicultura paulistana, que se deu nos sentidos noroeste e oeste sobre as linhas divisoras de águas entre os afluentes do Paraná, se reflete no enfileiramento de colônias urbanas e na distribuição da população rural ao longo dessas linhas mestras.

A principal direção da colonização também pode ser reconhecida claramente no norte do Paraná, e o modelo de expansão da população urbana e rural se parece com o exemplo paulistano. Contudo, a expansão no norte do Paraná até o rio Tibagi foi dificultada pela necessidade de se transpassar numerosos afluentes do rio Paranapanema que afluíam do sul. Somente a oeste do rio Tibagi se deu a continuidade da expansão em direção à principal linha divisora de águas.

O desenvolvimento das vias de acesso no fim da década de 1940 (Mapa 17) apresentava a orientação unilateral do Norte Novo e Novíssimo para o leste, ou seja, na direção de São Paulo. Havia falta de conexões transitáveis o ano todo para o sul. Com exceção da estrada principal de cascalho de Maringá a Londrina, todas as demais vias eram pistas naturais sem cobertura firme ou macadame. Após fortes chuvas, a maioria das estradas de terra roxa estavam interditadas devido à lama ou à pista escorregadia ${ }^{146}$.

Maringá era ligada a Campo Mourão, assim como a Paranavaí, por meio de vias naturais primitivas; rios tinham de ser atravessados por meio de balsas. Longe das linhas de conexão mais importantes havia somente caminhos simples e picadas.

A conexão ferroviária do Norte Novo com Curitiba, capital do Paraná, e com o porto de Paranaguá passava apenas por Ourinhos e Ponta Grossa, ou seja, cerca de 2 vezes e meia a distância que uma conexão direta entre Apucarana e Ponta Grossa compreenderia.

Em contraste com isso, surgiram numerosos voos regulares para São Paulo, mais raramente para Curitiba, que partiam, com exceção de Londrina, também das pequenas localidades pioneiras Mandaguari, Maringá e Campo Mourão.

O desenvolvimento do Norte Novo trouxe consigo o arroteamento de grandes áreas de floresta tropical semi-decídua na região da terra roxa (Mapa 18). As áreas mais afetadas foram as de maior altitude, devido à excelente adequação para o cultivo do café. Uma vez que a distribuição de terra nessa região do norte do Paraná foi feita em grande porcentagem em pequenas e médias propriedades de 30 a

145 Ver também a Tabela 12 sobre a mudança populacional no Norte do Paraná (p. 305, Anexo).

146 Waibel (1948, p. 628) fez uma descrição - que, à exceção da estrada principal, ainda é válida na época de publicação da primeira edição deste livro - da situação das vias de acesso nos arredores de Apucarana: Depois das chuvas “ [...] as ruas ficam cheias de caminhões que não conseguem prosseguir; comboios de ajuda saem em todas as direções e mesmo na cidade o trânsito inteiro se limita ao necessário“. 
50 ha, a parcela da área desmatada na área cultivável era de qualquer forma elevada. Na área da CTNP, a recomendação da Companhia para que se deixasse no mínimo $10 \%$ da área cultivável como floresta remanescente foi, na maioria da vezes, respeitada até o ano de 1950.

Na área estudada surgiram, em 1950, pouco mais de 20.000 fazendas com área cultivável de 1,3 milhões de hectares, das quais $57 \%$ somente no Norte Novo de Londrina, assim como suas respectivas áreas. A parcela da área utilizada para o plantio de produtos agrícolas na área cultivável total oscilava, na região mencionada, entre $70 \%$ no município de Cambé e 17\% no município de Londrina, cuja área, em sua maior parte, estava localizada fora da área da CTNP e era ainda pouco utilizada.

O contraste das dimensões da estrutura da dos estabelecimentos agrícolas pode ser visualizado pela comparação entre os municípios de Cambé (CTNP) e Porecatu:

Tabela 8: Dimensões da estrutura dos estabelecimentos agrícolas no Norte Novo em 1950

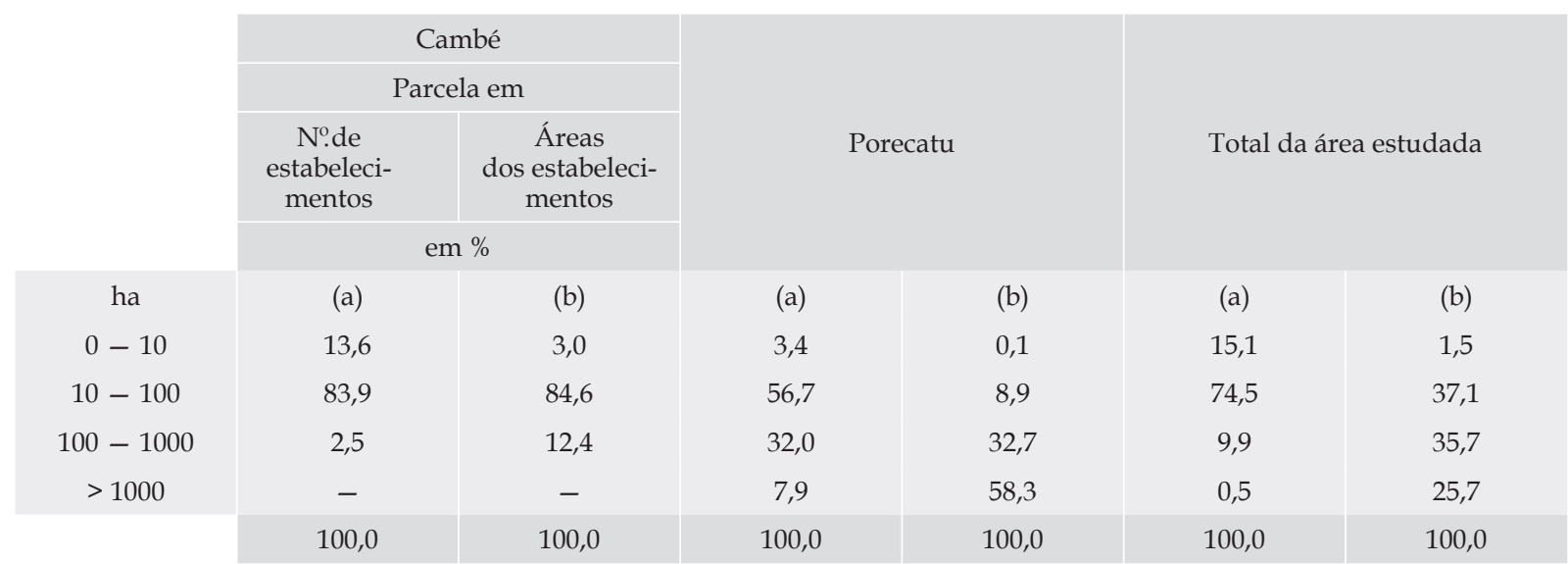

Fonte: CIBPU (1958).

Enquanto Cambé representava o modelo das dimensões das propriedades agrimensadas pela CTNP, surgiam, na região de Porecatu e Bela Vista do Paraíso, grandes plantações de cana-de-açúcar e café do grupo paulistano Lunardelli ${ }^{147}$.

A rápida expansão do cultivo do café por volta do fim da década de 1940 pode ser vista resumidamente com o auxílio da tabela a seguir:

Tabela 9: Número de pés de café e produção cafeeira no Norte Novo de 1942 a 1950

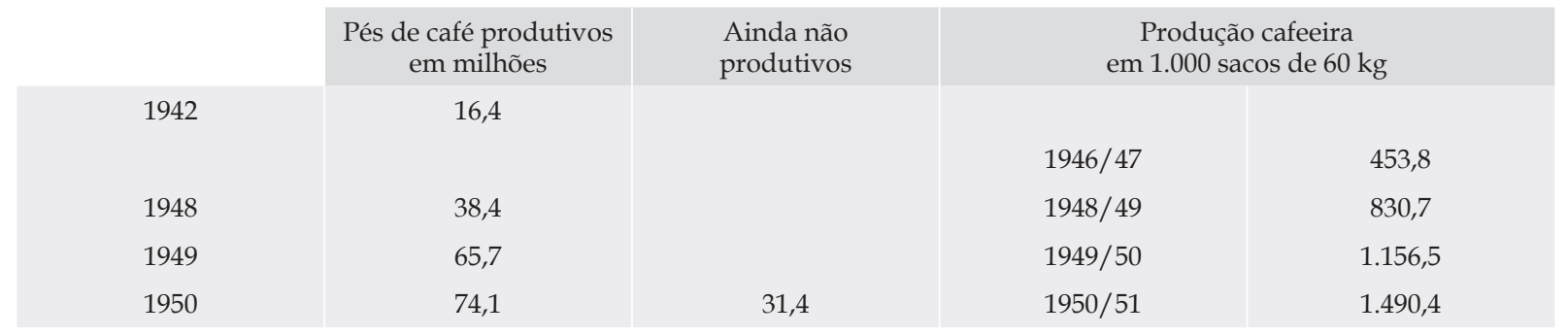

Fonte: Kretzen (1951, p. XXXVIII/XXXIX).

147 Por volta de 1950, G. Lunardelli era reconhecido, com 12 milhões de pés de café em São Paulo, Paraná, Mato Grosso e Goiás, como rei do café do Brasil (KRETZEN, 1951, S. 437). 
De 1948 a 1950 o número de pés de café produtivos duplicou, como consequência das novas plantações cultivadas desde 1945/46.

O extraordinário aumento expressivo da produção cafeeira no Paraná trouxe, com a elevação dos preços do café, grandes ganhos financeiros para o Norte Novo. Em 1950, dois terços dos bancos do Paraná já se encontravam no norte do estado, destes, 63 no Norte Novo. Entre os 10 municípios paranaenses com os maiores depósitos bancários, 8 estavam localizados na região de plantação de café, entre eles Londrina, Mandaguari, Arapongas, Cambé, Rolândia e Apucarana. Os créditos bancários de Londrina somavam mais de 50\% dos depósitos na capital Curitiba, tendo ainda que se levar em consideração o significativo afluxo financeiro do Norte do Paraná para São Paulo. A agência do Banco do Brasil em Londrina ficava, depois do Rio de Janeiro, São Paulo e Santos, em quarto lugar no Brasil em volume de negócios!

Na segunda metade da década de 1940, o café se tornou o produto de exportação mais importante do Paraná. A participação do Paraná na exportação brasileira aumentou em 7 vezes de 1946 ao início de 1951 e o Paraná havia passado da $7^{\mathrm{a}}$ a $2^{\mathrm{a}}$ colocação no ranking dos estados brasileiros na exportação, atrás de São Paulo.

Tabela 10: Participação do Paraná na exportação brasileira e participação do café na exportação paranaense entre 1942 e 1951

\begin{tabular}{|c|c|c|c|c|}
\hline & & $\begin{array}{c}\text { Participação do Paraná na expor- } \\
\text { tação brasileira, em \% }\end{array}$ & Colocação & $\begin{array}{c}\text { Participação do café na exporta- } \\
\text { ção do Paraná, em \% }\end{array}$ \\
\hline 1942 & & - & - & 9,3 \\
\hline 1946 & & 2,3 & $7^{\circ}$ & 20,6 \\
\hline 1948 & & 4,5 & $6^{\circ}$ & 32,3 \\
\hline 1949 & & 7,1 & $4^{\circ}$ & 43,1 \\
\hline 1950 & & 9,5 & $3^{\circ}$ & 55,4 \\
\hline 1951 & (janeiro-abril) & 16,3 & $2^{\circ}$ & . \\
\hline
\end{tabular}

Não há dados sobre o aumento da área plantada para os demais produtos agrícolas por município relativos ao período anterior a 1950. O aumento da área para o cultivo do café corresponde, contudo, no sistema de cultivo dominante no Paraná, a um aumento significativo da área de cultivo para as entressafras de milho, feijão e arroz montês, os quais são plantados entre os pés de café jovens nos 4 primeiros anos para suprir a demanda de alimentos básicos.

No aumento da aréa cultivável brasileira de 3,2 milhões de hectares entre 1939 e 1949, o Paraná teve uma participação individual de $28 \%$ !

Nos grandes vales dos rios, no entanto, a vegetação natural foi mantida, como, por exemplo, no vale do Tibagi (com exceção do 'corredor' da travessia leste-oeste em direção a Londrina), no vale do Pirapó e outros afluentes menores do Paranapanema. O vale do Ivaí ainda se encontrava tomado, em seu médio e baixo cursos, por florestas tropicais (Mapa 18). Os motivos para o desenvolvimento mais lento dos profundos vales dos grandes cursos d'água já foram mencionados, sendo eles a baixa adequação para o cultivo do café em decorrência da retenção de ar frio e o risco de malária nos meses quentes.

A frente de desmatamento avançou em um largo arco entre o Pirapó e o Ivaí na direção noroeste, sendo que o flanco sudoeste se dirigia, em sua extenção total entre Maringá e Apucarana, em direção ao Ivaí. Na área do arroteamento surgia, de forma bastante nítida, a conexão entre Maringá e Paranavaí. Ao longo da linha de separação de águas e em direção ao antigo caminho de gado é possível reconhecer um corredor quase contínio até o rio Paraná (Mapa 18). Enquanto as aréas de desmatamento que partiam de Maringá na direção sudoeste se achavam a apenas $10 \mathrm{~km}$ do rio Ivaí, partindo de Campo Mourão para o nordeste havia somente células de desmatamento isoladas na floresta tropical da bacia do Ivaí, onde, contudo, existia uma conexão de caminhos contínua.

Em um grau maior que as florestas tropicais do norte, as reservas valiosas de araucárias das regiões elevadas do Terceiro Planalto já haviam sido largamente exploradas. Nas regiões de floresta subtropical 
do sudoeste localizadas ao sul do Piquiri, o movimento de colonização do Rio Grande do Sul estava a todo vapor. Todavia, o impulso colonizatório do sul não deixou uma frente pioneira uniforme avançar para o norte, ocasionou, antes disso, uma fragmentação do frontier, como pode ser observado no Mapa 11.

Áreas isoladas do Norte Novo e toda a zona tropical do Norte Novíssimo que ainda não havia sido explorada proporcionaram amplo espaço para o avanço da 'colonização cafeeira' depois de 1950. 